\title{
Advances in Fenton and Fenton Based Oxidation Processes for Industrial Effluent Contaminants Control-A Review
}

\author{
Sina Matavos-Aramyan ${ }^{1 *}$ and Mohsen Moussavi ${ }^{2}$ \\ ${ }^{1}$ Young Researchers and Elite Club, Islamic Azad University, Iran \\ ${ }^{2}$ Department of Chemical Engineering, Islamic Azad University, Iran
}

Submission: April 28, 2017; Published: June 02, 2017

*Corresponding author: Sina Matavos-Aramyan, Young Researchers and Elite Club, Shiraz Branch, Islamic Azad University, Shiraz, Iran, Tel: +98 937 3294386; Fax: +98 21 89781867, Email: s.matavos@gmail.com

\begin{abstract}
This paper reviews the main advances in Fenton and Fenton-based systems as oxidation processes for environmental pollution abatement in three parts. The increase in the disposal of refractory organics demands for newer technologies for the complete mineralization of these wastewaters. Fenton reaction is an advanced oxidation process which has gained wide spread acceptance for higher removal efficiency of recalcitrant organic contaminants under wide range of operational conditions. However, the requirement of strict acidic conditions to prevent iron precipitation still remains the bottleneck for iron-based Fenton and Fenton-based processes.

The first part of this paper presents a literature review of the various Fenton reagent reactions which constitute the overall kinetic scheme with all possible side reactions. The second part presents a general review on Fenton and Fenton-based processes developed to degrade organic pollutants. Also fundamentals and main applications of typical methods such as Fenton, electro-Fenton, photo-Fenton, sonophoto-Fenton, sono-electro-Fenton and photo-electro-Fenton are discussed. The last part of this paper presents a review of alternative noniron Fenton catalysts and their reactivity towards hydrogen peroxide activation. Elements with multiple redox states, all directly decompose hydrogen peroxide into hydroxyl radicals through conventional Fenton-like pathways. This part of the present paper also highlights limitations influencing their environmental applications.
\end{abstract}

Keywords: Fenton's reagent; Wastewater treatment; Advanced oxidation processes; Hydrogen peroxide; Transition metal substituted iron oxide

Abbreviations: COD: Chemical Oxygen Demand; BOD: Biological Oxygen Demand; CMCD: Carboxymethyl b-Cyclodextrin; IBP: Ibuprofen; AMX: Amoxicillin; DOC: Dissolved Organic Carbon; PRE: Petroleum Refinery Effluent; ROS: Reactive Oxygen Species; MTBE: Methyl Tert-Butyl Ether; TAME: Tert-Amyl Methyl Ether

\section{Introduction}

The global concern about alternative water reuse techniques are increasing continuously as heavy industries such as petrochemicals and agricultures grows bigger each year. Those organic pollutants present in wastewaters which are not treatable by conventional treatment methods, are considered to be treated by stronger and more modern techniques. The presence of these organic compounds in water poses serious threat to public health since most of them are toxic, endocrine disrupting, mutagenic or potentially carcinogenic to humans, animals and aquatic life in general. Wastewaters containing these compounds are known to be high in chemical oxygen demand (COD) and low in biological oxygen demand (BOD). These nonbiodegradable molecules enter the environment predominantly through industrial activities.
Traditional wastewater management methods using biological microorganisms (biodegradation) and/or physicochemical processes (flocculation, chlorination, ozonation and misc.), subsequently followed by filtration and adsorption-based separations are able to treat a majority of anthropogenicallypolluted water sources. However, no single method described above is efficient enough to produce water with legally- and practically-acceptable levels of refractory toxic chemicals. Physico-chemical techniques like flocculation, adsorption and reverse osmosis require additional post-treatments to prevent secondary disposal and contamination [1]. Wet air oxidation of effluents with $>100 \mathrm{~g} / \mathrm{L}$ of chemical oxygen demand (COD) generates high concentrations of toxic byproducts like dioxins and furans [2]. Direct oxidation processes are widely used to 
degrade bio-refractory substances. High degradation efficiencies are possible with direct oxidation techniques. However, pollution load, process limitations and operating conditions are the key factors to be considered during the selection of most appropriate oxidation process for a particular compound degradation. Apart from high degradation efficiency, direct oxidation processes demand specified operating conditions to degrade the target compounds and this will increase the operation cost of the process [3-7].

Table 1: Advanced oxidation processes classification.

\begin{tabular}{|c|c|c|}
\hline Type of & cess & Example \\
\hline \multicolumn{3}{|c|}{ Heterogeneous } \\
\hline \multicolumn{2}{|c|}{ Using energy } & $\mathrm{TiO} 2 / \mathrm{ZnO} / \mathrm{CdS}+\mathrm{UV}$ \\
\hline \multicolumn{2}{|c|}{ Without energy } & $\begin{array}{c}\text { Catalytic ozonation } \\
\text { Photocatalytic ozonation } \\
\text { Heterogeneous photocatalysis } \\
\mathrm{H}_{2} \mathrm{O}_{2}+\text { nano-zero valent iron } \\
\mathrm{H}_{2} \mathrm{O}_{2}+\text { immobilized nano-zero } \\
\text { valent iron }\end{array}$ \\
\hline \multicolumn{3}{|c|}{ Homogeneous } \\
\hline \multirow{6}{*}{ Using energy } & $\begin{array}{l}\text { Ultraviolet } \\
\text { radiation }\end{array}$ & $\begin{array}{c}\mathrm{UV} / \mathrm{H}_{2} \mathrm{O}_{2}+\mathrm{Fe}^{2+} \\
\mathrm{O}_{3}+\mathrm{UV} \\
\mathrm{O}_{3}+\mathrm{UV}+\mathrm{H}_{2} \mathrm{O}_{2}\end{array}$ \\
\hline & $\begin{array}{l}\text { Ultrasound } \\
\text { energy }\end{array}$ & $\mathrm{US} / \mathrm{H}_{2} \mathrm{O}_{2}+\mathrm{Fe}^{2+} \mathrm{US} / \mathrm{O}_{3}$ \\
\hline & $\begin{array}{l}\text { Electrical } \\
\text { energy }\end{array}$ & $\begin{array}{l}\text { Electro-Fenton } \\
\text { Electrochemical oxidation } \\
\text { Anodic oxidation }\end{array}$ \\
\hline & $\begin{array}{l}\text { Ultrasound/ } \\
\text { Electrical } \\
\text { energy }\end{array}$ & Sono-electro-Fenton \\
\hline & $\begin{array}{l}\text { Ultraviolet/ } \\
\text { Electrical } \\
\text { energy }\end{array}$ & Photo-electro-Fenton \\
\hline & $\begin{array}{c}\text { Ultrasound/ } \\
\text { Ultraviolet } \\
\text { energy }\end{array}$ & Sono-photo-Fenton \\
\hline \multirow{3}{*}{ Without energy } & $\begin{array}{l}\text { Alkaline } \\
\text { medium }\end{array}$ & $\mathrm{O}_{3}$ in alkaline medium \\
\hline & $\begin{array}{l}\text { Combined } \\
\text { systems }\end{array}$ & $\mathrm{O}_{3} / \mathrm{H}_{2} \mathrm{O}_{2}$ \\
\hline & $\begin{array}{l}\text { Catalyzed } \\
\text { systems }\end{array}$ & $\mathrm{H}_{2} \mathrm{O}_{2} /$ catalyst \\
\hline
\end{tabular}

Advanced Oxidation Processes are those techniques which have the capabilities of utilizing the high reactivity of hydroxyl radicals in driving oxidation processes. The different types of AOPs are considered for wastewater pollution abatement [8]. The hydroxyl radicals are extraordinarily reactive species, which attack the most part of organic molecules with rate constants usually in the order of $106-109 \mathrm{M}^{-1} \mathrm{~s}^{-1}$ [9]. Hydroxyl radical is the second strongest oxidant preceded by the fluorine, and it reacts 106-1012 times faster than ozone depending on the substrate to be degraded $[3,10]$. Advanced oxidation processes can be classified either as homogeneous or heterogeneous.
Homogeneous processes can be further subdivided into processes that use energy and processes that do not use energy. A goal of the wastewater purification by means of AOP methods is the mineralization of the contaminants to carbon dioxide, water and inorganic or, at least, at their transformation into harmless products. Obviously the methods based on chemical destruction, when properly developed, give complete solution to the problem of pollutant abatement differently from those in which only a phase separation is realized with the consequent problem of the final disposal [3] (Table 1).

\section{Fenton Chemistry}

The oxidation processes utilizing activation of $\mathrm{H} 2 \mathrm{O} 2$ by iron salts are referred to as Fenton's reagent. This reaction allows the generation of hydroxyl radicals as shown in reaction (1) [11-13]: $\mathrm{Fe}^{2+}+\mathrm{H}_{2} \quad \mathrm{O}_{2} \rightarrow \mathrm{Fe}^{3+}+\mathrm{OH}^{-}+\mathrm{OH}$. (Chain initiation) $\mathrm{k}_{1}=70 \mathrm{M}^{-1} \mathrm{~s}^{-1}$ ------(1)

The generation of the radicals involves a complex reaction sequence in an aqueous solution:

$\mathrm{OH} .+\mathrm{Fe}^{2+} \rightarrow \mathrm{OH}+\mathrm{Fe}^{3+}($ chain termination $) \mathrm{k}_{2}=3.2 \times 108 \mathrm{M}^{-1} \mathrm{~s}^{-1}$ $-------(2)$

$\mathrm{Fe}^{3+}$ produced can react with $\mathrm{H}_{2} \mathrm{O}_{2}$ and hydroperoxyl radical in the so-called Fenton-like reaction, which leads to regenerating $\mathrm{Fe}^{2+}$ (reactions (3) and (5)). $\mathrm{Fe}^{2+}$ regeneration is also possible by reacting with organic radical intermediates (reaction (7)) $[10,11]$ :

$\mathrm{Fe}^{3+}+\mathrm{H}_{2} \mathrm{O}_{2} \rightarrow \mathrm{Fe}^{2+}+\mathrm{HO}_{2}+\mathrm{H}^{+} \quad \mathrm{k} 3=0.001-0.01 \mathrm{M}^{-1} \mathrm{~s}^{-1}$

$[15]----$ --.-- (3)

$\mathrm{HO}_{2}+\mathrm{Fe}^{2+} \rightarrow \mathrm{HO}_{2}+\mathrm{Fe}^{3} \quad \mathrm{k} 4=1.3 \times 106 \mathrm{M}^{-1} \mathrm{~s}^{-1}$ at $\mathrm{pH}=3$

--.-- (4)

$\mathrm{Fe}^{3+}+\mathrm{HO}_{2} \cdot \rightarrow \mathrm{Fe}^{2+}+\mathrm{O}_{2}+\mathrm{H}^{+} \quad \mathrm{k}_{5}=1.2 \times 106 \mathrm{M}^{-1} \mathrm{~s}^{-1}$ at $\mathrm{pH}=3$ ----- (5)

$\mathrm{OH} .+\mathrm{H}_{2} \mathrm{O}_{2} \rightarrow \mathrm{H}_{2} \mathrm{O}+\mathrm{HO}_{2} . \quad \mathrm{k} 6=3.3 \times 107 \mathrm{M}^{-1} \mathrm{~S}^{-1} \quad$ [17] -------

$\mathrm{Fe}^{3+}+\mathrm{R} . \rightarrow \mathrm{Fe}^{2+}+\mathrm{R}^{+}$

If the concentrations of reactants are not limiting, the organics can be completely detoxified by full conversion to $\mathrm{CO} 2$, water and in the case of substituted organics, inorganic salts if the treatment is continued.

Reaction (1) which is the overall Fenton chemistry is simplified [18] by accounting for the dissociation water:

$2 \mathrm{Fe}^{2+}+\mathrm{H}_{2} \mathrm{O}_{2}+2 \mathrm{H}^{+} \rightarrow 2 \mathrm{Fe}^{3+}+2 \mathrm{H}_{2} \mathrm{O}-----(8)$

This equation indicates the need for an acidic environment to produce the maximum amount of hydroxyl radicals. Previous Fenton studies have shown that acidic pH levels near 3 are usually optimum for Fenton oxidations [19]. At low pH levels and in the presence of organic substrates, hydroxyl radicals can abstract a hydrogen atom, initiating a radical chain oxidation [11,18-20]. 
$\mathrm{RH}+\mathrm{OH} . \rightarrow \mathrm{H}_{2} \mathrm{O}+\mathrm{R}$. (Chain propagation) --------- (9)

$\mathrm{R} .+\mathrm{H}_{2} \mathrm{O}_{2} \rightarrow \mathrm{ROH}+\mathrm{OH}$

$\mathrm{R} .+\mathrm{O}_{2} \rightarrow \mathrm{ROO}$

The sequence of reactions (1), (2), (9) and (7) constitute the present accepted scheme for the Fenton's reagent chain. The foregoing analysis indicates that hydrogen peroxide may act both as radical generator as in reaction (1) and as scavenger as in reaction (6) [11].

In the absence or presence of any organic molecule to be oxidized, the decomposition of hydrogen peroxide to molecular oxygen and water occurs according to reaction (10). This reaction leads to exploitation of bulk oxidant and thus an unnecessary increase on treatment cost $[3,21]$

$\mathrm{s} 2 \mathrm{H}_{2} \mathrm{O}_{2} \rightarrow \mathrm{O}_{2}+2 \mathrm{H}_{2} \mathrm{O}-----$

Fenton oxidation has been extensively applied to the treatment of diverse wastewaters from olive oil industries [22], textile industries [23], paper pulp factories [24], cork processing facilities [25] and winery industries [26], as well as effluents from refinery and fuel terminals [27], sludge waste [28], landfill leachate [29,30] and contaminated soils [31-33].

The main reasons for the huge popularity and widespread applicability of Fenton oxidation processes are [1]:

1. The high efficiency of mineralization enables the transformation of organic pollutants into non-toxic $\mathrm{CO}_{2}$,

2. Owing to the rapid reaction between iron and $\mathrm{H}_{2} \mathrm{O}_{2}$, the activation of $\mathrm{H}_{2} \mathrm{O}_{2}$ and the subsequent generation of hydroxyl radicals are completed in the shortest reaction time among all other AOPs [1,34],

3. Oxidizing radicals are generated at ambient pressure and temperature, which avoids the requirement of complicated reactor facilities,

4. The use of cheap, moderately reactive, and easy-tohandle reagents (iron and $\mathrm{H}_{2} \mathrm{O}_{2}$ ) makes the Fenton process cost effective and practically viable,

5. The simple and flexible nature enables easy implementation as a stand-alone or hybrid system and also facilitates easy integration in existing water treatment processes like coagulation, filtration and biological oxidation $[1,35,36]$.

However, two main drawbacks were identified. The first is related to the wastage of oxidants due to the radical scavenging effect of hydrogen peroxide as in reaction (6) and its selfdecomposition as in reaction (12). The second refers to the continuous loss of iron ions and the formation of solid sludge. Several economic and environmental drawbacks have been reported to occur with Fenton sludge [3,37]. Thus, technologies allowing an efficient use of $\mathrm{H}_{2} \mathrm{O}_{2}$ have to be studied. Furthermore, an attempt has to be made for the recovery of iron ions and their subsequent recycle and reuse. Although Fenton's reagent was discovered about 100 years ago, its application as an oxidizing process for destroying toxic organics was not applied until the late 1960's [3,38].

\section{Homogeneous vs. Heterogeneous Systems}

Iron species exist in the same phase with reactants in homogeneous Fenton reaction. Therefore, there is no mass transfer limitation. A large number of studies have been conducted successfully using iron salts in Fenton processes for treatment of various wastewaters. Despite significant mineralization efficiency of homogeneous Fenton processes under optimum condition, a number of limitations are associated with these processes. The main drawback is the formation of large quantity of ferric-hydroxide sludge at $\mathrm{pH}$ values higher than 4.0 [39], that poses in adverse effects on the environment and waste disposal issues. In addition, regeneration of catalyst is not only impracticable but also large amount of catalytic metal is misplaced in the sludge. These limitations can be overcome to some extent by application of heterogeneous catalysts. This category of catalysts has gained growing concern in Fenton process as its effectiveness is maintained for wider range of $\mathrm{pH}$. Iron is stabilized within the catalyst structure in heterogeneous catalysis and can effectively activate degradation of recalcitrant compounds without generation of ferric hydroxide precipitation. Nevertheless, heterogeneous catalysis is of slower oxidation rate compared to homogeneous reaction [40] due to the presence of a small fraction of iron on the catalyst surface. On this basis, recent investigations have focused on the development of new hetero-catalysts with larger surface area and higher activities in degradation processes $[3,39]$. Three possible mechanisms have been proposed for hetero-catalysts action in Fenton processes:

1. Iron leaching to the reaction solution and activating hydrogen peroxide through homogeneous pathway and/or

2. Decomposition of $\mathrm{H}_{2} \mathrm{O}_{2}$ to hydroxyl radicals by binding of $\mathrm{H}_{2} \mathrm{O}_{2}$ with iron species on the surface of catalyst and its decomposition to hydroxyl radicals or

3. Chemisorption of probe molecule on the catalyst surface [39-42].

Numerous heterogeneous catalysts have been used in Fenton reactions. Amongst them are iron minerals that are relatively less priced and can be separated magnetically from the reaction medium [43]. Details related to the application of different iron oxides in Fenton reactions and their degradation efficacy have been reviewed previously by the authors of this paper $[34,39]$. In addition, application of ferrites, clays, zeolite, alumina, fly ash based catalysts and other types of heterogeneous catalyst have been reviewed in detailed by other researchers [43-46]. Finally it should be pointed out that heterogeneous Fenton-like treatment of highly polluted wastewaters with low transparency is not 
practically efficient because of inner filtration effects related to large number of absorbing molecules and inhibition of photons absorption by iron cations $[39,47]$.

\section{Influence of Operational Condition}

Amongst various factors that influence the effectiveness of degradation process in the Fenton oxidation system, the concentrations of the contaminant and Fenton reagents, $\mathrm{pH}$ and temperature of the reaction medium are found to be the most significant factors. In this context, the optimization of the reaction is very important to achieve better treatment results.

\section{Structure of contaminants}

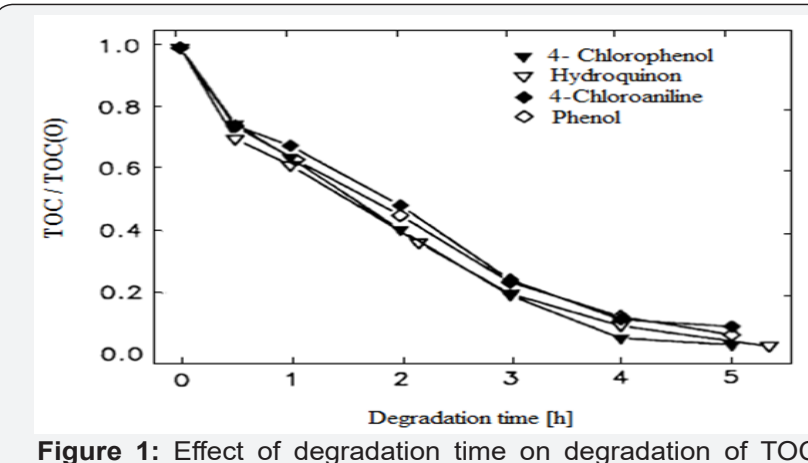

Figure 1: Effect of degradation time on degradation of TOC for 4-chlorophenol, hydroquinone, 4-chloroaniline and phenol (experimental conditions: [substrate] $0=1 \times 10^{-3} \mathrm{M}^{-1},\left[\mathrm{H}_{2} \mathrm{O}_{2}\right]_{0}=$ $\left.1 \times 10^{-2} \mathrm{M}^{-1},\left[\mathrm{Fe}^{2+}\right]_{0}=2.5 \times 10^{-4} \mathrm{M}^{-1}\right)[51]$.



Figure 2: Effect of degradation time on degradation of TOC for cyclohexanol, cyclohexanone, 4-nitroaniline and 3-nitroaniline (experimental conditions: [substrate]0 $=1 \times 10^{-3} \mathrm{M}^{-1},\left[\mathrm{H}_{2} \mathrm{O}_{2}\right] 0=$ $\left.1 \times 10^{-2} \mathrm{M}^{-1},\left[\mathrm{Fe}^{2+}\right]_{0}=2.5 \times 10^{-4} \mathrm{M}^{-1}\right)[51]$.

Kinetic degradation of aromatic pollutants with the Fenton system was reported earlier [48-50]; but less attention was given to the mineralization of these substances. The degradation of alicyclic compounds was given little attention since most of the water pollutants with a low biodegradability have an aromatic structure. The influence of the structure of several organic pollutants on the way they are mineralized by hydroxyl radicals has been studied [11,51]. As shown in (Figures $1 \& 2$ ), all of the aromatic substances studied by authors were strongly degraded after several hours, while the organic carbon of cyclohexanol and cyclohexanone was hardly attacked. In alicyclic compounds the attack of the electrophilic hydroxyl radicals cannot occur at conjugated $\mathrm{C}=\mathrm{C}$ double bonds in contrast to aromatic compounds where ring opening and further degradation take place. As shown in (Figures 3 \& 4), $\mathrm{H}_{2} \mathrm{O}_{2}$ decrease during reaction was in good correlation with the TOC (total organic carbon) degradation. For all aromatic substances studied degradation curves became linear after the first $30 \mathrm{~min}$, until $\mathrm{H}_{2} \mathrm{O}_{2}$ was completely exhausted. During degradation of cyclohexanol and cyclohexanone only a slight decrease of the oxidant could be observed [11]. The continued destruction of nitroaniline after exhaustion of $\mathrm{H}_{2} \mathrm{O}_{2}$, as shown in (Figure 2) was attributed to photo-Fenton reactions [51]

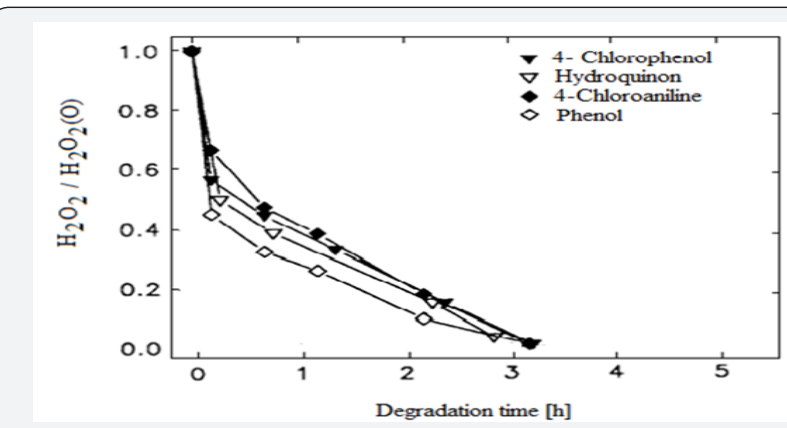

Figure 3: Effect of degradation time on degradation of $\mathrm{H}_{2} \mathrm{O}_{2}$ for 4-chlorophenol, hydroquinone, 4-chloroaniline and phenol (experimental conditions: [substrate] $0=1 \times$ $\left.10^{-3} \mathrm{M}^{-1},\left[\mathrm{H}_{2} \mathrm{O}_{2}\right] \mathrm{O}=1 \times 10_{-2} \mathrm{M}^{-1},\left[\mathrm{Fe}^{2+}\right]=2.5 \times 10^{-4} \mathrm{M}^{-1}\right)[51]$.

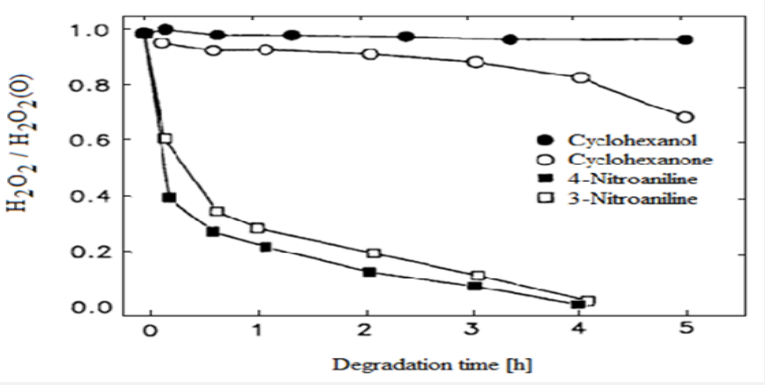

Figure 4: Effect of degradation time on degradation of $\mathrm{H} 2 \mathrm{O} 2$ for cyclohexanol, cyclohexanone, 4-nitroaniline and 3-nitroaniline (experimental conditions: [substrate] $0=1 \times$ $\left.10^{-3} \mathrm{M}^{-1},\left[\mathrm{H}_{2} \mathrm{O}_{2}\right] 0=1 \times 10^{-2} \mathrm{M}^{-1},\left[\mathrm{Fe}^{2+}\right] 0=2.5 \times 10^{-4} \mathrm{M}^{-1}\right)[51]$.

\section{Probe Molecules}

The contaminant concentration is one of the important factors in Fenton process dealing with photons. Literature survey has clearly revealed that the increase in concentration of probe molecule has negative effects on its removal efficiency due to the inner filtration effect related to high concentrations of absorbing molecules [52]. Consequently, it needs longer irradiation time and/or further magnification in Fenton reagents to supply adequate hydroxyl radicals into the reaction $[39,53]$.

\section{Operating $\mathrm{pH}$}

The main disadvantage often associated with homogeneous Fenton system is its $\mathrm{pH}$ dependency to achieve the best degradation efficiency [54]. This is a challenging issue especially in natural waters or highly buffered wastewaters. Fenton process is strongly dependent on the solution $\mathrm{pH}$ mainly due to iron and hydrogen peroxide speciation factors. The optimum $\mathrm{pH}$ 
for the Fenton reaction was found to be around 3, regardless of the target substrate [55-58]. The activity of Fenton reagent is reduced at higher $\mathrm{pH}$ due to the presence of relatively inactive iron oxohydroxides and formation of ferric hydroxide precipitate [59]. In this situation, less hydroxyl radicals are generated due to the presence of less free iron ions. The oxidation potential of hydroxyl radicals decreases with increasing $\mathrm{pH}$. In addition, auto-decomposition (reaction (12)) of hydrogen peroxide is accelerated at high $\mathrm{pH}[3,60]$. In general higher-than-optimum pH values disturb Fenton efficiency through:

1. Prevention of $\mathrm{H}_{2} \mathrm{O}_{2}$ decomposition to generate hydroxyl radicals due to the deficiency of $\mathrm{H}^{+}$ions [18],

2. Accelerated decomposition of $\mathrm{H}_{2} \mathrm{O}_{2}$ to water and oxygen at $\mathrm{pH}$ values above 5 ,

3. Decline in oxidation potential of hydroxyl radicals (E0 $=2.8-1.95 \mathrm{~V}$ at $\mathrm{pH} 0-14$ ) [61],

4. Possible generation of more selective ferric species other than hydroxyl radicals at $\mathrm{pH}$ above 5 [62] and

5. Development of ferric oxyhydroxide (Fe-OOH) at $\mathrm{pH}$ above 4 that reduces degradation rate [63]. At $\mathrm{pH}$ values above 4 , iron precipitates as ferric hydroxide [39,55,6365].

At $\mathrm{pH}$ below 3, decrease in degradation efficiency was observed [66]. At very low pH values, iron complex species $\left[\mathrm{Fe}\left(\mathrm{H}_{2} \mathrm{O}\right)_{6}\right]^{2+}$ exists, which reacts more slowly with hydrogen peroxide than other species [67]. In addition, the peroxide gets solvated in the presence of high concentration of $\mathrm{H}^{+}$ions to form stable oxonium ion $\left[\mathrm{H}_{3} \mathrm{O}_{2}\right]^{+}$. Oxonium ions make hydrogen peroxide more stable and reduce its reactivity with ferrous ions $[3,66,68]$. Therefore, the efficiency of the Fenton process to degrade organic compounds is reduced both at high and low $\mathrm{pH}$. Thus an adequate control of $\mathrm{pH}$ would increase process efficiency. It should be noted that the type of buffer solution used also has effect on the degradation process [69]. The acetic acid/ acetate buffer gives maximum oxidation efficiency whereas least is observed with phosphate and sulfate buffers [69]. This can be attributed to the formation of stable $\mathrm{Fe} 3+$ complexes that are formed under those conditions $[3,70]$.

\section{Ferrous ion concentration}

The Fenton reaction begins by producing hydroxyl radicals from the reaction between ferrous ion and hydrogen peroxide (reaction (1)). When the Fenton reaction in the absence of organics is initiated under $\left[\mathrm{Fe}_{2}+\right] 0 /\left[\mathrm{H}_{2} \mathrm{O}_{2}\right] 0 \geq 2$, the consumption ratio of ferrous ion to hydrogen peroxide becomes about 2 , and radical chain reactions are quickly terminated. This is because the hydroxyl radicals produced as a result of reaction (1) mainly react with the ferrous ion and not hydrogen peroxide. This explanation is supported by the fact that the reaction between hydroxyl radicals and the ferrous ion is ten times faster than that between hydroxyl radicals and hydrogen peroxide $\left(\mathrm{k}_{2}=3.2 \times\right.$ $108 \mathrm{M}^{-1} \mathrm{~s}^{-1}$ and $\left.\mathrm{k} 6=3.3 \times 107 \mathrm{M}^{-1} \mathrm{~s}^{-1}\right)[11,17]$.
Usually the rate of degradation increases with an increase in the concentration of ferrous ion [71]. However, the extent of increase is sometimes observed to be marginal above a certain concentration of ferrous ion $[55,72,73]$. Also, an enormous increase in the ferrous ions will lead to an increase in the unutilized quantity of iron salts, which will contribute to an increase in the total dissolved solids content of the effluent stream and this is not permitted. Thus, laboratory scale studies are required to establish the optimum loading of ferrous ions to mineralize the organics [3].

\section{Hydrogen peroxide concentration}

Concentration of hydrogen peroxide plays a crucial role in deciding the overall efficiency of the degradation process [3]. It has been observed that the degradation percent of the pollutant increases with an increase in the dosage of hydrogen peroxide [56,71-73]. However, care should be taken while selecting the operating oxidant dosage. The unused portion of hydrogen peroxide during the Fenton process contributes to COD [71] and hence excess amount is not recommended. Also, the presence of hydrogen peroxide is harmful to many of the organisms [74] and will affect the overall degradation efficiency significantly, where Fenton oxidation is used as a pretreatment to biological oxidation [3].

With hydrogen peroxide concentrations at an average $\left[\mathrm{Fe}^{2}+\right] 0 /\left[\mathrm{H}^{2} \mathrm{O}^{2}\right] 0$ ratio $=1$, regardless of the presence of organics, hydrogen peroxide rapidly converts all ferrous to ferric ions via reaction (1). In the absence of $\mathrm{RH}$, hydrogen peroxide decomposes slowly through ferric ion induced radical chain reactions (reaction (3)) just after the rapid consumption of hydrogen peroxide. The reduction of the ferric ion (reactions (3)) is significantly lower than reaction (1) and is the ratedetermining step. To have a continued decrease of hydrogen peroxide, ferrous ion must be formed by the reduction of ferric ion. Then, the Fenton reaction can be characterized by two specific systems, i.e. the ferrous system and the ferric system, which depend on the oxidation stage of the iron initially added or the major oxidation state of the iron present. The ferrous system refers to the case where the primary reaction, which produces hydroxyl radical, is the reaction between the ferrous ion and hydrogen peroxide (reaction (1)) $[11,12]$.

\section{Initial concentration of pollutant}

In general, lower initial concentration of the pollutants is favored [68,69], but the negative effects of treating large quantities of effluent need to be analyzed before the dilution ratio is fixed. For real industrial wastewaters, dilution is essential before any degradation is effected by Fenton oxidation [3].

\section{Temperature}

A large number of studies related to Fenton-based methods have been carried out at room temperature $[39,75-$ 77]. This is because thermal decomposition of $\mathrm{H}_{2} \mathrm{O}_{2}$ occurs at temperatures above $50^{\circ} \mathrm{C}$ [78-84]. In addition, due to the fact 
that $\mathrm{H}_{2} \mathrm{O}_{2}$ decomposition is accelerated at basic $\mathrm{pH}$ values, the increment in temperature brings about a shift in optimum $\mathrm{pH}$ towards acidic values $[39,75,80]$. In fact, a study [71] reported an optimum temperature of $30^{\circ} \mathrm{C}$, whereas another study [55] reported that the degradation efficiency is unaffected even when the temperature is increased from 10 to $40^{\circ} \mathrm{C}$. If the reaction temperature is expected to rise beyond $40^{\circ} \mathrm{C}$ due to exothermic nature, cooling is recommended. The efficient utilization of hydrogen peroxide decreases due to accelerated decomposition of hydrogen peroxide into water and oxygen [3,81]. However, based on the Arrhenius theory of rate constants in relation to temperature, it is expected that increase in temperature leads to higher generation of hydroxyl radicals from the increase in concentration of produced $\mathrm{Fe}(\mathrm{OH})^{2+}$ [82]. In another study, complete mineralization of diclofenac, a phenyl containing drug compound was attained when the experiments were carried out at $50^{\circ} \mathrm{C}$ [83]. However, the authors did not report any data regarding degradation efficiency at ambient temperature [39].

\section{Chemical coagulation}

Chemical coagulation step is recommended after Fenton oxidation to keep the concentration of the soluble iron with the specified limits [71]. A study [72] has demonstrated the efficacy of chemical coagulation in controlling the concentration of total dissolved solids below the specified limits [3].

\section{Composition of Reaction Medium}

Besides main operational conditions, there are several other factors that affect the efficiency of Fenton and Fenton-based oxidations. Amongst them is the composition of the treated water. Inorganic ions such as carbonates, bicarbonates, chlorides, fluoride, bromide, phosphate and sulfate may be present in water or generated via degradation process. Some of these ions may alter oxidation rate of Fenton reactions [39]. The extent of the change in reaction kinetic depends on the type of ion and its concentration in the solution through one or combination of the following effects:

- formation of Fe(III) complexes and lessening of the abundance and activity of iron species,

- generation of by-products that are in some cases more toxic and recalcitrant than parent compounds,

- hydroxyl radical scavenging and generation of less reactive radicals than hydroxyl radicals,

- $\quad$ reaction of generated radicals with hydrogen peroxide that decreases its availability in solution,

- $\quad$ competition with organic compounds for active sites on hetero-catalysts, and

- $\quad$ Effect on ferrous ion recovery [39,84-91].

\section{Chelating Agents}

Despite the fact that Fenton processes provide acceptable scores for contaminant degradation in acidic solutions, a large number of recent works have employed several inorganic or organic ligands such as EDTA, EDDS, oxalate, NTA, carboxymethyl b-cyclodextrin (CMCD), tartrate, citrate and succinate, to improve its efficiency and to increase the oxidation rate of probe molecules [39,91-94]. The positive effects of these ions can be attributed to the following aspects:

- having higher quantum yield of hydroxyl radical formation compared to other Fe (III) complexes,

- $\quad$ promoting the reduction of ferric ion to ferrous ion and accordingly, regeneration of higher amounts of hydroxyl radical $[39,95,96]$,

- promoting $\mathrm{H}_{2} \mathrm{O}_{2}$ activation and hydroxyl radical generation,

- $\quad$ enhancing the solubilization of lipophilic organic pollutants, and

- Enhancing iron dissolution at neutral pH via photochemical reduction of $\mathrm{Fe}^{3+}$ to $\mathrm{Fe}^{2+}[39,91,93]$.

\section{Energy-Consuming Fenton-Based Reactions}

\section{Photo-Fenton processes}

A combination of hydrogen peroxide and UV radiation with $\mathrm{Fe}^{2+}$ or $\mathrm{Fe}^{3+}$ oxalate ion (photo-Fenton (PF) process) produces more hydroxyl radicals compared to conventional Fenton method or photolysis and in turn increases the rate of degradation of organic pollutants [97-104]. Fenton reaction accumulates $\mathrm{Fe}^{3+}$ ions in the system and the reaction does not proceed once all $\mathrm{Fe}^{2+}$ ions are consumed. The photochemical regeneration of ferrous ions $\left(\mathrm{Fe}^{2+}\right)$ by photo-reduction (reaction (13)) of ferric ions $(\mathrm{Fe} 3+$ ) occurs in photo- Fenton reaction [105]. The newly generated ferrous ions react with $\mathrm{H}_{2} \mathrm{O}_{2}$ and generate hydroxyl radical and ferric ion, and the cycle continues [3]:

$$
\mathrm{FeOH}_{2}++\mathrm{h} v \rightarrow \mathrm{Fe}^{2+}+\mathrm{OH} \text {. }
$$

The studies reported in the literature showed that the combination of Fenton reaction with conventional radiation zone of the visible and near ultraviolet gives a better degradation of organic pollutants. Pollutants such as 4-chlorophenol [101], nitrobenzene and anisole [102], herbicides [98] and ethylene glycol [103] were degraded effectively by photo-Fenton process [3].

A study [104] compared the degradation of two commercial anionic surfactants such as sodium dodecyl sulfate and dodecylbenzenesulfonate, using Fenton reagents $\left(\mathrm{Fe}^{2+}\right.$ or $\mathrm{Fe}^{3+}$ with $\mathrm{H}_{2} \mathrm{O}_{2}$ in the presence or absence of solar radiation), photocatalysis $\left(\mathrm{TiO}_{2}\right.$ with solar irradiation) and photo-degradation using solar sensitizer (pyrylium salt). They demonstrated that the addition of the solar sensitizer did not efficiently degrade the surfactants and their further studies concluded that the photoFenton processes using solar radiation $\left(0.1 \mathrm{mM}\right.$ of $\mathrm{Fe}^{2+}$ or $\mathrm{Fe}^{3+}$, and $1 \mathrm{mM} \mathrm{H}_{2} \mathrm{O}_{2}$ ) had a higher rate of surfactant degradation than that of solar-TiO ${ }_{2}$ treatment [3]. 


\section{Sono-Photo-Fenton Process}

The combined treatment using ultrasound and ultraviolet along with Fenton reagent is known as sono-photo-Fenton (SPF) process, which enhanced the production of hydroxyl radicals in an aqueous system significantly. Sonolysis of water produces hydroxyl radicals and hydrogen atoms. However, significant loss of $\mathrm{H}$.and hydroxyl radical species occurs due to the recombination. On the other hand, the applications of UV light, converted the hydrogen peroxide produced by recombination of hydroxyl radicals, and in turn increased the amount hydroxyl radical [105]. The intermediate complex formed due to the reaction of $\mathrm{Fe} 3+$ with $\mathrm{H}_{2} \mathrm{O}_{2}$ during the Fenton reaction could be reduced to $\mathrm{Fe}^{2+}$ by sonolysis [106] and photolysis $[3,107]$. The degradation of recalcitrant pharmaceutical micro-pollutant ibuprofen (IBP) by means of sono-photo-Fenton, sonophoto-catalysis and $\mathrm{TiO}_{2} / \mathrm{Fe}^{2+} /$ sonolysis processes has been investigated [108]. The presence of ultrasound irradiation in photo-Fenton process improved the iron catalytic activity and ibuprofen degradation and mineralization to $95 \%$ and $60 \%$, respectively. On the other hand, total removal of ibuprofen and elimination of more than $50 \%$ of dissolved organic carbon were observed by photo catalysis with $\mathrm{TiO}_{2}$ in the presence of ultrasound irradiation [3]. The results showed that, the hybrid system is a promising method for complete elimination/ mineralization of the recalcitrant micro-contaminant ibuprofen.

\section{Sono-electro-Fenton process}

Many researchers have reported the coupling strategy between sonochemistry and different AOPs such as the Fenton process giving rise to the concept of advanced sonochemical hybrid techniques that possess significantly greater efficacy for water remediation [109-111]. Hydroxyl radicals produced by water decomposition are used for the degradation of organics $[3,111]$. The effect of low frequency ultrasonic irradiation on the sono-electro-Fenton oxidation of cationic red XGRL has been evaluated [112]. Ultrasonic irradiation significantly increased the hydrogen peroxide production rate and reduced the time needed to reach the maximum hydrogen peroxide concentration. In addition, ultrasonic irradiation has a considerable effect on the degradation of cationic red X-GRL. The results showed that the degradation rate followed pseudo-first order kinetics and also decolorization rate increased with ultrasonic power. Furthermore, total organic carbon removal efficiency and mineralization were greatly promoted in sono-electro-Fenton process compared to electro-Fenton process [3]. These results proved that sono-electro- Fenton process is a promising technology in terms of colored wastewater treatment.

\section{Photo-electro-Fenton process}

The catalytic effect of $\mathrm{Fe}^{2+}$ in the electro-Fenton process can be enhanced by irradiating the contents with UV light. Thus, the combination of electrochemical and photochemical process with Fenton process is called photo-electro-Fenton process generates greater quantity of free radicals due to the combination effect
$[113,114]$. The direct photolysis of an acid solution containing peroxide generates hydroxyl radicals through the breakdown of the peroxide molecule according to reaction (14). This reaction increased the oxidative capability of the process due to the additional production of hydroxyl radicals. Thus, the degradation of target organic substrate can be enhanced when the solution is irradiated with UV light in addition to the application of electroFenton process. Photochemical regeneration of $\mathrm{Fe}^{2+}$ by the photo reduction of $\mathrm{Fe}^{3+}$ ions and photo-activation of complexes renders the photo-electro-Fenton systems more efficient $[3,115,116]$. At acidic $\mathrm{pH}$, oxalic acid derivatives behave as the photo-active complexes in the presence of ferric ions which undergo photodecarboxylation reaction [19] as shown in reaction (15).

$$
\begin{aligned}
& \mathrm{H}_{2} \mathrm{O}_{2}+\mathrm{h} v \rightarrow 2 \mathrm{OH} .---(14) \\
& \mathrm{R}\left(\mathrm{CO}_{2}\right) \mathrm{Fe}(\mathrm{III})+\mathrm{h} v \rightarrow \mathrm{RCO}_{2} \cdot \mathrm{Fe}(\mathrm{II})+\mathrm{R} .+\mathrm{CO}_{2}
\end{aligned}
$$

The studies pertaining to the application of photo-electroFenton process are very limited and most of the studies are related to the treatment of herbicide [113,115,117], 4-chloro-2methylphenol [118] and dyes [119]. In another study [120] solar photo-energy is recently used as photon source and reduced the operating costs of the process substantially [3].

\section{Application of Fenton and Fenton Based Systems in Industries}

There have been extensive studies on application of Fenton and Fenton-based systems for treatment of various industrial wastewaters and synthetic recalcitrant solutions at laboratory or pilot plant scales. Amongst them are dyes which are the major organic pollutants. Photo-Fenton treatment of synthetic solutions of dyes such as acid blue, acid orange 7 and acid red 151 [121], remazol red RR [40], orange II [122], procion red H-E7B and cibacron red FN-R [123] and 218 also real dye wastewaters [124-127] are examples that have recently been reported. In addition, Fenton-based systems application exclusively or in combination with other processes for treatment of industrial wastewaters such as winery [128], pulp mill [129], cork boiling [130], plastic containers washing [131], pharmaceutical [132] and alkydic resins [133] have been well documented. Despite a large number of studies on dye/textile wastewaters treatment by homogeneous and/or heterogeneous Fenton-based systems, it has been reviewed previously by a number of researchers $[39,134]$. Accordingly, this part of the present review focuses on the application of these oxidation processes for treatment of pharmaceuticals, agrochemicals and petroleum refinery effluents.

\section{Pharmaceuticals}

Pharmaceutical plants generate wastewaters containing toxic solvents and intermediates that are usually lipophilic and non-biodegradable in regard to accepting media. Besides pharmaceutical manufacturing discharges, other sources are effluents containing personal care products, hospital wastewaters and veterinary effluents. Inappropriately treated 
pharmaceutical effluents results in several problems such as occurrence of antibiotic-resistant bacteria, interference in human endocrine system and feminization of higher organisms [135-138]. However, the potential effects of a large number of these active chemicals in co-existence with other chemicals on human being and other living organisms are not entirely understood $[39,139]$. Literature has shown that the effectiveness of conventional treatment methods for recalcitrant pharmaceutical wastewaters is limited. In contrast, AOPs have shown great ability for oxidizing and mineralizing many nonbiodegradable pharmaceuticals. Various AOPs such as ozonation [140], sonolysis [141], UV/ $\mathrm{H}_{2} \mathrm{O}_{2}$ system [142], wet air oxidation [143], Fenton oxidation [144] and photo-Fenton process have been applied for pharmaceuticals degradation in water and wastewater $[39,145]$.

Although pharmaceutical wastewater treatment by homogeneous Fenton-based processes has been reported as one of the most appropriate methods amongst AOPs, its degradation efficiency depends on COD: $\mathrm{H}_{2} \mathrm{O}_{2}: \mathrm{Fe}^{2+}$ ratio and the $\mathrm{pH}$ range of 2.5-4 [142]. Trovo et al. [146] studied paracetamol, a pain reliever drug, degradation by solar Fenton-based processes using FeSO 4 and potassium ferrioxalate (Fe-Ox). The degradation was enhanced with $\mathrm{FeSO} 4$ as compared to $\mathrm{Fe}-\mathrm{Ox}$. This can be related to the effects of $\mathrm{FeSO} 4$ in forming large amount of hydroxylated intermediates and accordingly, increasing in the generation of $\mathrm{Fe}^{2+}$ through $\mathrm{Fe}^{3+}$ reduction. On the other hand, complete degradation of amoxicillin (AMX) was obtained using Fe-Ox with only 5 min of irradiation, in comparison with FeSO 4 that took 15 min [147]. Kajitvichyanukul and Suntronvi part [148] employed photo-Fenton process as a pre-treatment step to enhance the oxidation degree of hospital effluents at laboratory scale. Complete COD removal was obtained by sequential activated sludge treatment which is a less costly post-treatment method [39].

\section{Agrochemicals}

The increase in food and fiber production has always been connected to the use of pesticides [149]. Pesticides including herbicides, insecticides and fungicides are used based on their specific biological activity on target species [150]. Besides cultivated areas, one of the most important sources of pesticide contamination is discharges from pesticide production plants [151]. In general, pesticides affect the health of living organisms directly and are toxic and carcinogenic in nature even at microconcentrations [152]. Generally, pesticides are removed from industrial wastewaters by physical-chemical methods due to the shock doses associated with pesticides and their toxicity to microbial cultures [153]. Literature reviews confirm Fentonbased processes as effective methods for degradation of recalcitrant agrochemicals. In addition, Fenton-based processes have been reported as one of the most appropriate pretreatment/treatment systems compared to other AOPs [39]. For example, Teixeira et al. [154] carried out aphoto-Fenton process along with $\left(\mathrm{H}_{2} \mathrm{O}_{2} / \mathrm{UV}\right),\left(\mathrm{TiO}_{2} / \mathrm{UV}\right)$ and conventional Fenton for decontamination of wastewaters containing active compounds of a fungicide (tebuconazole) and an insecticide (methamidophos) at laboratory scale. The results indicated that the photo-Fenton process performed better compared to other AOPs at all tested $\mathrm{Fe}^{2+}$ and $\mathrm{H}_{2} \mathrm{O}_{2}$ concentrations.

In addition, Fenton-based processes were able to reduce dissolved organic carbon (DOC) and COD to $32 \%$ and $27 \%$ respectively after $60 \mathrm{~min}$. Methomyl is known as a highly toxic carbamate insecticide [155] that is highly soluble in water. The study on the removal efficiency of this toxic chemical using Fenton and Fenton-based processes was carried out by Tamimi et al. [65]. Complete degradation of methomyl was attained after 30 min of irradiation whereas its removal degree with Fenton oxidation was $86.1 \%$ after $60 \mathrm{~min}$. Lower reaction time 3.96 min vs. $13.86 \mathrm{~min}$ ) and higher oxidation rate (0.1750 $\mathrm{min}-1$ vs. $0.0500 \mathrm{~min}^{-1}$ ) were observed for Fenton-based processes compared to the Fenton process. In another study, Maldonado et al. [156] compared the efficiency of photo-Fenton with $\mathrm{TiO}_{2}$ photo catalysis and Fenton process for degradation of a number of pesticides (alachlor, atrazine, chlorfenvinphos, diuron, isoproturon and pentachlorophenol) and a mixture of them. The authors reported photo-Fenton process as the most suitable system for mineralization of these compounds and their mixture with the advantage of shorter reaction time (38-79\%) compared to $\mathrm{TiO}_{2}$ photo catalysis. In addition, total TOC removal was obtained in Fenton-based systems after less than 15 min of irradiation, while no mineralization of atrazine and isoproturon took place using Fenton process. The photo-reactivity of the pesticides was reported in the following order: diuron $>$ alachlor $>$ isoproturon $>$ chlorfenvinphos $>$ atrazine with similar behavior in both mixture and individual treatments [39].

\section{Petroleum Refinery plant}

Petroleum refinery plant transforms crude oil into multitude refined products. Besides air pollution, the generated effluent is of concern [157]. Large amounts of water, that is about 0.41.6 times the quantity of the processed crude oil, is used for refining processes of cooling system, distillation, hydro-treating, and desalting [158]. This wastewater may expose various contaminants into the aquatic environment. Petroleum refinery effluent (PRE) has high concentrations of aliphatic and aromatic compounds especially polycyclic hydrocarbons along with oil and grease [159] in which aromatic fraction is more toxic and recalcitrant than aliphatic portion [160-163]. The aromatics are therefore the principal issue in degradation due to their toxicity and potential hazards. Generally, PREs are characterized by high COD, low biodegradability (BOD5/COD <0.4) and large fraction of high molecular-weight organic compounds $[158,163,164]$. Several treatment technologies such as adsorption [165], coagulation and flocculation [166], bioremediation [167], electrochemical processes [168], membrane technology [169] and different advanced oxidation processes of wet air oxidation [170], photolysis [160], Fenton [104] and photo-Fenton $[158,171]$ have been used for petroleum refinery wastewaters. 
However, biological treatment has exhibited poor performance for complete removal of refractory chemicals from PREs [172]. Coelho et al. [158] carried out Fenton-based processes for DOC removal of petroleum refinery sour water. They conducted batch oxidation experiments in a two-step (Fenton and photo-Fenton) and one-step (photo-Fenton) process. There were $87 \%$ and $70 \%$ DOC removal, demonstrating improvement in degradation with a decrease in energy consumption in treatment process by applying combined processes [39]. PhotoFenton oxidation system was also tested on treatment of water contaminated by diesel oil in a study by Galvao et al. [171]. In this study, although the amount of ferrous ion was very low ( $0.1 \mathrm{mmol} \mathrm{L-1)}$, the TOC removal was up to $99 \%$. However, only $28 \%$ and $26 \%$ mineralization of diesel oil were obtained using UV photolysis and thermal Fenton oxidation. Nevertheless, longer irradiation time in $\mathrm{UV} / \mathrm{H}_{2} \mathrm{O}_{2}$ process could increase the mineralization up to $71 \%$. Similarly, da Silva et al. [173] reported $89 \%$ of TOC removal in a wastewater containing xylene by applying $0.26 \mathrm{mmol} \mathrm{L}-1 \mathrm{Fe}^{2+}$ when the allowable limit of $\mathrm{Fe}^{2+}$ was $0.27 \mathrm{mmol} \mathrm{L}-1$ [39].

Practically, it is not conceivable to judge the effectiveness of all Fenton-based processes for PREs based on the present available studies. More studies on simulated and real PREs with complex matrices, instead of one organic compound, is required to their effectiveness on comparison. In addition, due to complex nature of PREs, combination of Fenton or Fenton-based processes with a series of pretreatment and/or post-treatment processes will be helpful to achieve cost effective and acceptable results [39].

\section{Transition Metal Substituted Iron Oxide Catalysts}

Since both homogeneous and heterogeneous iron-based Fenton AOPs show severe practical disadvantages, research efforts are being focused on finding new practically acceptable and economically-viable Fenton catalysts to generate hydroxyl radical from $\mathrm{H}_{2} \mathrm{O}_{2}$. In this regard, to achieve an efficient electron transfer to $\mathrm{H}_{2} \mathrm{O}_{2}$, the ideal Fenton catalyst should exhibit multiple oxidation states because the catalytically-active species with a specific oxidation state can be easily regenerated from an inactive form through a simple redox cycle. To achieve this objective, both active and inactive redox states should be stable over a wide $\mathrm{pH}$ range to prevent the precipitation of the catalytic species. Elements with multiple oxidation states efficiently decompose $\mathrm{H} 2 \mathrm{O} 2$ even at neutral $\mathrm{pH}$ in both homogeneous and heterogeneous reaction conditions. While the exact activation mechanism is strictly dependent on the nature of the catalyst, it is effectively controlled by solution $\mathrm{pH}$ and/or metal-ligand complexation. Importantly, redox transformation of these nonferrous metal species is easily achieved using the $\mathrm{pH}$-dependent dual role of $\mathrm{H}_{2} \mathrm{O}_{2}$ as both oxidant and reductant [1].

\section{Aluminum}

In homogeneous aqueous solution, the only accessible oxidation state for aluminum ( $\mathrm{Al})$ is $\mathrm{Al}^{3+}$. Thus, unlike the case of iron with both $\mathrm{Fe}^{2+}$ and $\mathrm{Fe}^{3+}$ states, the electron transfer reaction between $\mathrm{Al}^{3+}$ and $\mathrm{H}_{2} \mathrm{O}_{2}$ is not possible. On the other hand, the charge transfer using zero-valent aluminum (Al0 or $\mathrm{ZVAl}$ ) as the electron source is thermodynamically more efficient: $\mathrm{ZVAl}\left[\mathrm{E} 0\left(\mathrm{Al}^{3+} / \mathrm{Al} 0\right)=-1.66 \mathrm{~V}\right]$ provides a much stronger thermodynamic driving force for the electron transfer to $\mathrm{H}_{2} \mathrm{O}_{2}$ $\left[\mathrm{E} 0\left(\mathrm{H}_{2} \mathrm{O}_{2} / \mathrm{HO}\right.\right.$. $)=0.8 \mathrm{~V}$ at $\mathrm{pH}$ 7] compared to $\mathrm{Fe} 0\left[\mathrm{E} 0\left(\mathrm{Fe}^{2+} / \mathrm{Fe}_{0}\right)\right.$ $=-0.44 \mathrm{~V}]$ or $\mathrm{Fe}^{2+}\left[\mathrm{E} 0\left(\mathrm{Fe}^{3+} / \mathrm{Fe}^{2+}\right)=+0.776 \mathrm{~V}\right]$. This enhanced electron transfer capacity of ZVAl was first demonstrated in 1991 to reduce nitrate to ammonia in aqueous solution [174]. Ten years later, Lien and co-workers $[175,176]$ reported the oxidation of organic substrates using electron transfer from surface-functionalized aluminum metal. Using bifunctional aluminum prepared by sulfated Zale with sulfuric acid, electron transfer to molecular oxygen $\left(\mathrm{O}_{2}\right)$ generated reactive oxygen species (ROS) for the oxidation of methyl tert-butyl ether (MTBE) and tert-amyl methyl ether (TAME) [1]. The sulfate species on the ZVAl surface enhanced the oxidation efficiency by first stabilizing the ROS on the active sites and then adsorbing the organic substrate to initiate oxidation.

The use of ZVAl to decompose $\mathrm{H}_{2} \mathrm{O}_{2}$ into hydroxyl radicals for pollutant oxidation has major advantages such as high natural abundance (most abundant metal in earth's crust) and low weight (three times lighter than Fe). However, the surface Al203 layer cannot be easily removed in neutral or near-neutral $\mathrm{pH}$ conditions, which restricts the practical applications of ZVAl-based AOP systems to strictly acidic environments (below $\mathrm{pH}_{4}$ ), similar to Fe based Fenton processes. Nevertheless, the ZVAl aerobic system still exhibits significantly higher oxidative capacity compared to Fe-based one, mainly owing to the high reduction potential and the enhanced aqueous solubility of $\mathrm{Al}^{3+}$ species [177]. Thus, within the same practical limitations (acidic effluents only), the use of ZVAl offers an efficient alternative for ex situ oxidation processes [1].

\section{Cerium}

Among all rare-earth or lanthanide group elements, cerium is the only metal capable of activating $\mathrm{H}_{2} \mathrm{O}_{2}$ by Fenton-like mechanism. Due to its $4 \mathrm{f} 26 \mathrm{~s} 2$ valence configuration, cerium is the only rare earth element to exhibit both +3 and +4 oxidation states in solution. While the cerous $\left(\mathrm{Ce}^{3+}\right)$ form is a strong reducing agent and easily oxidized by 02 in alkaline condition, the ceric $\left(\mathrm{Ce}^{4+}\right)$ species is a strong oxidant under acidic condition. Thus, cerium can easily cycle between the $\mathrm{Ce}^{3+}$ and $\mathrm{Ce}^{4+}$ oxidation states under suitable redox conditions $\left[\mathrm{E} 0\left(\mathrm{Ce}^{4+} / \mathrm{Ce}^{3+}\right)=+1.72\right.$ V]. To exploit this simple redox transformation for catalytic applications, cerium oxide $\left(\mathrm{CeO}_{2}\right.$ or ceria) is the most popular choice among all cerium compounds. Owing to the presence of oxygen vacancies on the oxide surface, the availability of surface $\mathrm{Ce}^{3+}$ at such defect sites is enhanced and induces high catalytic activity [178]. In addition, the easy formation and elimination of oxygen defects [179] during catalytic applications allow the repeated redox cycles of $\mathrm{Ce}_{4+} / \mathrm{Ce}_{3+}$ on the particle surface. Thus, 
$\mathrm{CeO}_{2}$ is widely used in catalytic wet air oxidation, water gas-shift reaction, and three-way automobile exhaust converters $[1,180]$.

A series of in-depth investigations of the $\mathrm{CeO}_{2} / \mathrm{H}_{2} \mathrm{O}_{2}$ Fentonlike system by Chen and coworkers [181-184] revealed that the production of hydroxyl radicals (and overall oxidation mechanism) critically depends on the oxide surface properties. Without any surface modification, the reaction between $\mathrm{Ce}^{3+}$ and $\mathrm{H}_{2} \mathrm{O}_{2}$ leads to the formation of stable brown peroxide-like species ( $\equiv \mathrm{Ce}^{3+}-\mathrm{OOH}-$ ), which remain stable even at neutral $\mathrm{pH}$ and do not directly decompose to generate free hydroxyl radicals $[182,183]$. Thus, bare cerium oxide is incapable of Fenton-like oxidation based on hydroxyl radicals [1]. However, these peroxide species easily decompose into hydroxyl radicals when cerium oxide is pre-treated using sulfuric acid (sulfated). The $\mathrm{CeO}_{2} /$ $\mathrm{H}_{2} \mathrm{O}_{2}$ heterogeneous redox system can be easily manipulated by simple surface modification to efficiently generate hydroxyl radicals under mild acidic condition. Due to the critical role of surface $\mathrm{Ce}^{3+}$ species on the catalytic efficiency, the use of nanosized ceria particles will further amplify the effective surface concentration of $\mathrm{Ce}^{3+}$ and increase the overall hydroxyl radical's yield. However, considering the acute cytotoxicity of cerium (both ionic and oxide forms) to aquatic life, plant species, and human beings [185], the catalytic stability and post-treatment disposal of cerium oxide catalysts need to be thoroughly examined before practical applications [1].

\section{Chromium}

Chromium (Cr) can theoretically exist in multiple oxidation states (from - 2 to +6 ) but only the trivalent [Cr(III)] and hexavalent [Cr(VI)] species are commonly detected in water. Under the Eh$\mathrm{pH}$ range of natural water, the cationic $\mathrm{Cr}$ (III) is the prevalent species at low $\mathrm{Eh}$ and $\mathrm{pH}$ values, whereas $\mathrm{Cr}(\mathrm{VI})$ exists as anionic CrO42- or Cr2072- in oxidizing conditions. While $\mathrm{Cr}(\mathrm{III})$ is an essential micronutrient for animals and plants and is critically involved in sugar metabolism [186], Cr(VI) is a Group 'A' human carcinogen and causes mutagenic liver damage, pulmonary congestion, and allergic dermatitis [187]. This contrasting toxicity profile is critically dependent on the aqueous solubility characteristics of both chromium species. The trivalent $\mathrm{Cr}(\mathrm{III})$ is easily precipitated as insoluble chromium hydroxide $[\mathrm{Cr}(\mathrm{OH}) 3]$ in neutral and alkaline conditions $(\mathrm{pH}>5)$, but the hexavalent $\mathrm{Cr}(\mathrm{VI})$ is completely water soluble in the entire pH range [1]. Despite their different aqueous solubility behavior and inherent toxicity, both trivalent and hexavalent chromium species react strongly with $\mathrm{H} 2 \mathrm{O} 2$ and generate hydroxyl radicals via a series of Fenton-like processes.

The reaction between $\mathrm{Cr}(\mathrm{VI})$ (present as oxyanion CrVIO42-) and $\mathrm{H}_{2} \mathrm{O}_{2}$ initiates the replacement of oxo ligands by peroxo groups and one-electron reduction of the metal center to form a [CrV(02)4]3-complex, which subsequently decomposes to form hydroxyl radicals and regenerate $\mathrm{Cr}(\mathrm{VI})$ [187-189]. Although the dissociation of this $\mathrm{Cr}(\mathrm{V})$-complex into hydroxyl radicals is strongly favored at acidic $\mathrm{pH}$, the oxidation of various organic pollutants was achieved even in neutral and near-alkaline conditions [188]. This indicated the formation of a reactive $\mathrm{Cr}(\mathrm{V})$ intermediate in a wide $\mathrm{pH}$ range (3.0-9.0), which is an advantage of using $\mathrm{Cr}(\mathrm{VI})$ for Fenton-like activation of $\mathrm{H}_{2} \mathrm{O}_{2}$. The high aqueous solubility of $\mathrm{Cr}(\mathrm{VI})$ is also an additional merit for using $\mathrm{Cr}(\mathrm{VI}) / \mathrm{H}_{2} \mathrm{O}_{2}$ as a homogeneous AOP. However, despite these practically-favorable reaction conditions, the extreme toxicity of $\mathrm{Cr}(\mathrm{VI})$ prohibits any deliberate addition into wastewater treatment. Nevertheless, the $\mathrm{Cr}(\mathrm{VI}) / \mathrm{H}_{2} \mathrm{O}_{2}$ redox system is ideal for the treatment of wastewaters already co-contaminated with $\mathrm{Cr}(\mathrm{VI})$ [1] and organic compounds such as effluents from leather tanning, electroplating and petroleum refining industries.

\section{Cobalt}

Divalent cobalt ion $\left(\mathrm{Co}^{2+}\right)$ has been widely investigated as a Fenton-like catalyst for the oxidation of organic pollutants. Using the $\mathrm{Co}^{2+} / \mathrm{Co}^{3+}$ redox couple $\left[\mathrm{E} 0\left(\mathrm{Co}_{3}+/ \mathrm{Co}^{2+}\right)=+1.92 \mathrm{~V}\right]$, a majority of studies have largely focused on the activation of persulfate (S2082-) or peroxymonosulfate (HSO5-) to generate sulfate radicals (SO4.-) as the main oxidant species [1]. Despite the fact that $\mathrm{Co}^{2+}$ demonstrates the best efficiency for SO4.generation compared to all other transitional metals $[190,191]$, the generation of hydroxyl radicals by $\mathrm{Co}^{2+}$-mediated activation of $\mathrm{H}_{2} \mathrm{O}_{2}$ has been documented only in a few studies.

Ling et al. [192] first investigated the homogeneous $\mathrm{Co}^{2+} /$ $\mathrm{H}_{2} \mathrm{O}_{2}$ redox system for the complete oxidation of basic blue dye and reported a strong correlation between $\left[\mathrm{H}_{2} \mathrm{O}_{2}\right]$ and degradation efficiency. Similar studies using photo-Fenton [193] and electro-Fenton [194] processes based on soluble $\mathrm{Co}^{2+}$ salts and $\mathrm{H}_{2} \mathrm{O}_{2}$ also demonstrated efficient oxidation capacity. However, the existence of a Fenton-like oxidation pathway via formation of hydroxyl radicals was not discussed or confirmed in all three reports. On the other hand, the oxidation of organic pollutants by heterogeneous $\mathrm{Co}^{2+}$ catalysts like $\mathrm{Co}^{2+} / \mathrm{Al} 2 \mathrm{O} 3$ [195], $\mathrm{Co}^{2+} / \mathrm{MCM}-41$ [196] and $\mathrm{Co}^{2+} /$ carbon aerogel [197] was also achieved in the presence of $\mathrm{H}_{2} \mathrm{O}_{2}$. The proposed reaction mechanism suggested the formation of a colored peroxo-cobalt complex on the catalyst surface [1], and further reaction with the organic substrate to generate organic radicals (reactions 16-18) [195]:

$$
\begin{aligned}
& \mathrm{SCo}^{2+}\left(\mathrm{H}_{2} \mathrm{O}\right) 4+\mathrm{H}_{2} \mathrm{O}_{2} \leftrightarrow \mathrm{SCo}_{2}+\left(\mathrm{H}_{2} \mathrm{O}\right) 4 \mathrm{OOH}+\mathrm{H}^{+} \\
& \mathrm{SCo}^{2+}\left(\mathrm{H}_{2} \mathrm{O}\right) 4(\mathrm{OOH})+\mathrm{R} \rightarrow \mathrm{SCo}_{2}+\left(\mathrm{H}_{2} \mathrm{O}\right) 4+\mathrm{ROOH} .(\text { or R }) .- \\
& \mathrm{SCo}^{2+}\left(\mathrm{H}_{2} \mathrm{O}\right) 4+\mathrm{H}_{2} \mathrm{O}_{2} \rightarrow \mathrm{SCo}^{2+}\left(\mathrm{H}_{2} \mathrm{O}\right) 4+1 / 2 \mathrm{O}^{2+} \mathrm{H}_{2} \mathrm{O}-\cdots
\end{aligned}
$$

Where $>\mathrm{S}$ refers to the support matrix and $\mathrm{R}$ denotes organic pollutant. However, the decomposition of peroxo-cobalt complex to generate hydroxyl radicals and its possible involvement in the overall oxidation pathway (HO. + R $\rightarrow$ R.) was not explored [1].

\section{Copper}

In terms of its reactivity towards $\mathrm{H}_{2} \mathrm{O}_{2}$, copper shows strikingly similar redox properties like iron. Both the monovalent $\left(\mathrm{Cu}^{+}\right)$and divalent $\left(\mathrm{Cu}^{2+}\right)$ oxidation states react easily with $\mathrm{H}_{2} \mathrm{O}_{2}$ 
(reactions (19) and (20)), analogous to the $\mathrm{Fe}^{2+} / \mathrm{H}_{2} \mathrm{O}_{2}$ and $\mathrm{Fe} 3+/$ H2O2 reaction systems, respectively [1].

$$
\begin{aligned}
& \mathrm{Cu}^{2+}+\mathrm{H}_{2} \mathrm{O}_{2} \rightarrow \mathrm{Cu}^{+}+\mathrm{HO}_{2}+\mathrm{OH}-\cdots-\cdots \\
& \mathrm{Cu}^{2+}+\mathrm{H}_{2} \mathrm{O}_{2} \rightarrow \mathrm{Cu}^{2+}+\mathrm{OH} .+\mathrm{OH}-\cdots----
\end{aligned}
$$

The hydrolyzed complex with the most stable oxidation state, i.e., $\mathrm{Cu}(\mathrm{OH})_{2}$ for $\mathrm{Cu}^{2+}$ and $\mathrm{FeOH}\left(\mathrm{H}_{2} \mathrm{O}\right)^{2+}$ for $\mathrm{Fe}^{3+}$, are both Fenton-active catalysts [198]. However, there is a strong difference in the aqueous solubility characteristics of $\mathrm{Cu}^{2+}$ and $\mathrm{Fe}^{3+}$. While the iron aquo complex $\left[\mathrm{Fe}\left(\mathrm{H}_{2} \mathrm{O}\right)_{6]}{ }^{3+}\right.$ is insoluble at $\mathrm{pH}>5$, the corresponding copper complex $\left[\mathrm{Cu}\left(\mathrm{H}_{2} \mathrm{O}\right)_{6}\right]^{2+}$ is predominant in neutral $\mathrm{pH}$ conditions [199]. This means that [1] the $\mathrm{Cu}^{2+} / \mathrm{H}_{2} \mathrm{O}_{2}$ Fenton-like system should work over a broader $\mathrm{pH}$ range, compared to the $\mathrm{Fe}^{3+} / \mathrm{H}_{2} \mathrm{O}_{2}$ redox system working only in the acidic condition. Accordingly, all $\mathrm{Cu}^{2+}$ - based Fenton catalysts efficiently generate hydroxyl radicals for the oxidation of various organic pollutants in near-neutral or neutral aqueous solutions. Additionally, $\mathrm{Cu}^{2+}$ complexes with organic degradation intermediates (organic acids) are easily decomposed by hydroxyl radicals, whereas, the corresponding $\mathrm{Fe}^{3+}$ complexes are highly stable [200,201]. As a result, unlike $\mathrm{Fe}^{3+}$ - based systems, $\mathrm{Cu} 2+$ complexation does not block (or deactivate) the Fenton reaction nor prevents complete mineralization of organic pollutants $[1,199]$. Thus, considering the similarities with $\mathrm{Fe}^{3+} /$ $\mathrm{H}_{2} \mathrm{O}_{2}$ Fenton-like system combined together with high catalytic stability in neutral conditions, the cupric ion $\left(\mathrm{Cu}^{2+}\right)$ satisfies all basic redox criteria required to activate $\mathrm{H}_{2} \mathrm{O}_{2}$ in large-scale practical applications.

\section{Manganese}

Compared to cobalt and copper, manganese (Mn) can exist in more variety of oxidation states ranging from 0 to +7. Although manganate $\left(\mathrm{Mn}^{6+}\right)$ and permanganate $\left(\mathrm{Mn}^{7+}\right)$ compounds are highly stable, only the oxidation states of ${ }^{+2}$ to +4 have environmental and catalytic significance. Both $\mathrm{Mn}^{2+}$ and Mn3+ compounds are water-soluble, whereas all naturally occurring manganese species (minerals and ores) contain predominantly $\mathrm{Mn}^{3+}$ and $\mathrm{Mn}^{4+}$ in oxide forms $\left(\mathrm{Mn}_{3} \mathrm{O}_{4}, \mathrm{Mn}_{2} \mathrm{O}_{3}\right.$ and $\mathrm{MnO}_{2}$ ). However, manganese exists only as $\mathrm{Mn}^{2+}$ or $\mathrm{Mn}^{4+}$ in the aquatic environment and the "bioavailable" divalent form is stable only at low $\mathrm{pH}(\mathrm{pH}<4)$ and in reducing conditions [202]. In aerobic neutral conditions, the complete oxidation of $\mathrm{Mn}^{2+}$ to $\mathrm{Mn} 4+$ involves the intermediate formation of colloidal $\mathrm{Mn}^{3+}$ oxyhydroxides and subsequent conversion into $\mathrm{MnO}_{2}$ [1]. The tetravalent $\mathrm{Mn}$ species can be easily reduced to $\mathrm{Mn}^{2+}$ through chemical redox processes (reaction (21)), which makes $\mathrm{MnO}_{2}$ a powerful oxidant for direct transformation of aqueous toxins [203].

$\mathrm{MnO}_{2}+\mathrm{S} \rightarrow \mathrm{Mn}^{2+}+$ Oxidized-S -------- (21)

Where $S$ represents the organic/inorganic substrate. Therefore, the facile inter-conversion between $\mathrm{Mn}^{2+}$ and $\mathrm{Mn}^{4+}$ via intermediate $\mathrm{Mn}^{3+}$ species should enable the Mn-catalyzed Fenton-like activation of $\mathrm{H}_{2} \mathrm{O}_{2}$ [1]. Despite the large variations in catalyst properties and radical characteristics, the oxide reactivity does not change significantly in the $\mathrm{pH}$ range 3.57.0 [204]. Mn dissolution does not occur above pH 5.5, which highlights the stability and easy recyclability for repeated oxidation cycles [1]. Therefore, manganese oxides offer many advantages for heterogeneous Fenton applications such as:

- optimal performance in near-neutral conditions,

- $\quad$ selective formation of ROS by careful choice of oxide composition, and

- High natural abundance of structurally-different oxide compounds [1].

\section{Ruthenium}

Among the transition metal catalysts, ruthenium $(\mathrm{Ru})$ is the only member of the platinum group metal that exhibits Fentonlike activity in the presence of $\mathrm{H}_{2} \mathrm{O}_{2}$. Although the possible oxidation states of $\mathrm{Ru}$ range from 0 to +8 , only the divalent $\left(\mathrm{Ru}^{2+}\right)$, trivalent $\left(\mathrm{Ru}^{3+}\right)$ and tetravalent $\left(\mathrm{Ru}^{4+}\right)$ oxidation states are commonly found. Ruthenium complexes have been widely investigated for various organic transformation reactions like olefin hydroxylation, alcohol dehydrogenation, water oxidation and alkene epoxidation [1,205]. However, only limited studies on the oxidation of organic pollutants using Ru-mediated $\mathrm{H}_{2} \mathrm{O}_{2}$ decomposition have been published so far [1].

Using the $\mathrm{Ru}^{3+} / \mathrm{Ru}^{2+}$ redox couple $\left[\mathrm{E} 0\left(\mathrm{Ru}^{3+} / \mathrm{Ru}^{2+}\right)=+1.29\right.$ V], the oxidation of bisphenol A was achieved by Hu et al. [206] using $\mathrm{Ru}^{2+}$-polypyridyl complex immobilized on cation exchange resins Dowex-50W and Chelex-100. The reaction between $\mathrm{Ru}^{2+}$ and $\mathrm{H}_{2} \mathrm{O}_{2}$ efficiently generated hydroxyl radicals in the $\mathrm{pH}$ range 4.0-8.0 with the oxidation efficiencies increasing at higher $\mathrm{pH}$. The use of resin supports not only prohibited the leaching of the $\mathrm{Ru}$ complex but also facilitated the repeated oxidation cycles and easy catalyst recovery. On the other hand, Rokhina et al. [207] investigated the oxidation of phenol using porous RuI3 catalyst (anhydrous powder form) as an activator of $\mathrm{H}_{2} \mathrm{O}_{2}$ [1]. Analogous to the $\mathrm{Fe}^{3+} / \mathrm{H}_{2} \mathrm{O}_{2}$ Fenton-like system, the in situ formation of $\mathrm{Ru}^{2+}$ upon the reduction of $\mathrm{Ru}^{3+}$ initiated the decomposition of $\mathrm{H}_{2} \mathrm{O}_{2}$ into hydroxyl radicals. The high stability of these $\mathrm{Ru}$ catalysts prevents metal leaching and allows multiple catalytic cycles. The latter is more important since $\mathrm{Ru}$ is an expensive and rare element. Therefore, the practical use of the Ru-based Fenton systems may be limited to the cases requiring exceptionally high catalytic performance and specialized reaction conditions [1].

\section{Conclusion}

It is difficult to treat wastewaters from pharmaceutical, agrochemical and petroleum refinery plants effectively by conventional methods due to their recalcitrant nature and resistance to bio-degradation. Advanced oxidation processes are found to be an environmental friendly process for the degradation of refractory compounds. Among advanced oxidation processes, Fenton and Fenton-based reaction treatment processes are 
known to be very effective in the removal of many hazardous organic pollutants from environment.

The popularity of Fenton and Fenton-based advanced oxidation processes for wastewater treatment has been credited mostly to the choice of iron-based catalysts. However, because of the restricted solubility of iron species, research efforts have focused on the establishment of iron-free Fenton systems for the activation of $\mathrm{H}_{2} \mathrm{O}_{2}$. Iron oxides as heterogeneous catalysts demonstrated considerable improvements in Fenton reactions for contaminant removal from polluted medium/sites due to their higher activity under a broad range of $\mathrm{pH}$ in contrast with soluble iron salts. The conclusions derived from the various literature sources can be stated as follows:

1. Catalytic materials with multiple oxidation states and redox stability efficiently decompose $\mathrm{H}_{2} \mathrm{O}_{2}$ to generate $\mathrm{HO}$ even in neutral/alkaline conditions in both homogeneous and heterogeneous reaction conditions.

2. The cytotoxic nature of soluble species like cerium, chromium and cobalt seriously limits the extent of large-scale applications, with only restricted usage permitted in controlled reaction conditions.

3. The development of ultra-stable heterogeneous metal complexes with enhanced reactivity for $\mathrm{H}_{2} \mathrm{O}_{2}$ and zero metal leaching remains the focal point to establish practically-viable and environmentally-sustainable iron-free Fenton systems.

4. Hybrid methods are not economically viable techniques to degrade large quantum of effluent disposed by the industries. Hence it is advisable to use these methods as pretreatment to reduce the toxicity to a certain level beyond which biological treatment can be employed.

5. Drawbacks associated with the use of Fenton and Fentonbased oxidation are the safety hazards associated with using $\mathrm{H}_{2} \mathrm{O}_{2}$ and the need to firstly reduce the $\mathrm{pH}$, followed by a subsequent neutralization.

6. Chelating agents stabilize iron species in the solution and prevent sludge production at $\mathrm{pH}$ values higher than 4.0 and increase Fenton degradation efficiency through several routes.

Major attention should be devoted in the future on the identification of reaction intermediates, development of rate expressions based on established reaction mechanisms, identification of scale-up parameters and criteria for cost effectiveness. These studies should aim at addressing different challenges to overcome $\mathrm{pH}$-dependency of the reaction and its future industrial applications by using solar energy which can minimize relevant energy cost.

\section{References}

1. Bokare A, Choi W (2014) Review of iron-free Fenton-like systems for activating $\mathrm{H}_{2} \mathrm{O}_{2}$ in advanced oxidation processes. J Hazard Mater 275: $121-135$
2. Tyagi VL, Lo SL (2011) Application of physico-chemical pretreatment methods to enhance the sludge disintegration and subsequent anaerobic digestion: an up to date review. Rev Environ Sci Biotechnol 10: $215-242$.

3. Babuponnusami A, Muthukumar K (2014) A review on Fenton and improvements to the Fenton process for wastewater treatment. J Environ Chem Eng 2(1): 557-572.

4. Kritzer P, Dinjus E (2001) An assessment of supercritical water oxidation (SCWO): existing problems, possible solutions and new reactor concepts. Chem Eng J 83(3): 207-214.

5. Kolaczkowski ST, Plucinski P, Beltran FJ, Rivas FJ, McLurgh DB (1999) Wet air oxidation: a review of process technologies and aspects in reactor design. Chem Eng J 73(2): 143-160.

6. Levec J, Pintar A (2007) Catalytic wet air oxidation processes. A review. Catal Today 124(3-4): 172-184.

7. Malato S, Blanco J, Vidal A, Richter C (2002) Photocatalysis with solar energy at a pilot-plant scale: an overview. Appl Catal B: Environ 37(1): $1-15$.

8. Glaze WH, Kang JW, Chapin DH (1987) The chemistry of water treatment processes involving ozone, hydrogen peroxide and ultraviolet radiation. Ozone Sci Eng 9(4): 335-352.

9. Hoigne J (1997) Inter-calibration of $\mathrm{OH}$ radical sources and water quality parameters. Water Sci Technol 35(4): 1-8.

10. Weast RC (1977) Hand Book of Chemistry and physics, (58 ${ }^{\text {th }}$ Edn.), CRC Press, Ohio, US.

11. Neyens E, Baeyens J (2003) A review of classic Fenton's peroxidation as an advanced oxidation technique. J Hazard Mater 98(1-3): 33-50.

12. Yoon J, Lee Y, Kim S (2001) Investigation of the reaction pathway of $\mathrm{OH}$ radicals produced by Fenton oxidation in the conditions of wastewater treatment. Wat Sci Technol 44(5): 15-21.

13. Lu MC, Lin CJ, Liao CH, Ting WP, Huang RY (2001) Influence of pH on the dewatering of activated sludge by Fenton's reagent. Wat Sci Techno 44(10): 327-332.

14. Rigg T, Taylor W, Weiss J (1954) The rate constant of the reaction between hydrogen peroxide and ferrous ions. J Chem Phys 22(4): 575577.

15. Walling C, Goosen A (1973) Mechanism of the ferric ion catalysed decomposition of hydrogen peroxide: effects of organic substrate. J Am Chem Soc 95(9): 2987-2991.

16. Bielski BH, Cabelli DE, Arudi RL (1985) Reactivity of $\mathrm{H}_{2} \mathrm{O}_{2} / \mathrm{O}_{2}$-radicals in aqueous solution. J Phys Chem Ref Data 14(4): 1041-1100.

17. Buxton GV, Greenstock CL (1988) Critical review of rate constants for reactions of hydrated electrons. J Phys Chem Ref Data 17(2): 513-886.

18. Walling C (1975) Fenton's reagent revisited. Acc Chem Res 8(4): 125131.

19. Arnold SM, Hickey WJ, Harris RF (1995) Degradation of atrazine by Fenton's reagent: condition optimization and product quantification. Environ Sci Technol 29(8): 2083-2089.

20. Lipczynska-Kochany E, Sprah G, Harms S (1995) Influence of some groundwater and surface waters constituents on the degradation of 4-chlorophenol by the Fenton reaction. Chemosphere 30(1): 9-20.

21. Pignatello JJ, Oliveros E, Mackay A (2006) Advanced oxidation processes for organic contaminant destruction based on the Fenton reaction and related chemistry. Crit Rev Environ Sci Tech 36(1): 1-84.

22. Lucas MS, Peres JA (2009) Treatment of olive mill wastewater by a combined process: Fenton's reagent and chemical coagulation. J Environ Sci Health A Tox Hazard Subst Environ Eng 44(2): 198-205.

23. Soares PA, Silva TF, Manenti DR, Souza SM, Boaventura RA, et al. (2014) 
Insights into real cotton-textile dyeing wastewater treatment using solar advanced oxidation processes. Environ Sci Pollut Res Int 21(2): 932-945.

24. Amat AM, Arques A, Lopez F, Miranda MA (2005) Solar photo-catalysis to remove paper mill wastewater pollutants. Sol Energy 79(4): 393401

25. Vilar VJ, Maldonado MI, Oller I, Malato S, Boaventura RA (2009) Solar treatment of cork boiling and bleaching wastewaters in a pilot plant. Water Res 43(16): 4050-4062.

26. Mosteo R, Ormad MP, Ovelleiro JL (2007) Photo-Fenton processes assisted by solar light used as preliminary step to biological treatment applied to winery wastewaters. Water Sci Technol 56(2): 89-94.

27. Hasan DB, Aziz AR, Daud WM (2012) Oxidative mineralization of petroleum refinery effluent using Fenton-like process. Chem Eng Res Des 90(2): 298-307.

28. Pham TT, Brar SK, Tyagi RD, Surampalli RY (2010) Influence of ultrasonication and Fenton oxidation pre-treatment on rheological characteristics of wastewater sludge. Ultrason Sonochem 17(1): 38-45

29. Deng Y, Englehardt JD (2006) Treatment of landfill leachate by the Fenton process. Water Res 40(20): 3683-3694.

30. Umar M, Aziz HA, Yusoff MS (2010) Trends in the use of Fenton, electro-Fenton and photo-Fenton for the treatment of landfill leachate. Waste Mgmt 30(11): 2113-2121.

31. Ravikumar JX, Gurol MD (1992) Fenton's reagent as a chemical oxidant for soil contaminants. Chem Oxid 2: 206-229.

32. Watts RJ, Teel AL (2005) Chemistry of modified Fenton's reagent (catalyzed $\mathrm{H}_{2} \mathrm{O}_{2}$ propagations-CHP) for in situ soil and groundwater remediation. J Environ Eng 131(4): 612-622.

33. Yap CL, Gan S, Ng HK (2011) Fenton based remediation of polycyclic aromatic hydrocarbons-contaminated soils. Chemosphere 83(11): 1414-1430.

34. Pouran SR, Raman AA, Daud WM (2013) Review on the application of modified iron oxides as heterogeneous catalysts in Fenton reactions. J Clean Prod 64: 24-35.

35. Brillas E, Sirés I, Oturan MA (2009) Electro-Fenton process and related electrochemical technologies based on Fenton's reaction chemistry. Chem Rev 109(12): 6570-6631.

36. Mantzavinos D, Psillakis E (2004) Enhancement of biodegradability of industrial wastewaters by chemical oxidation pre-treatment. J Chem Technol Biotechnol 79(5): 431-454.

37. Benatti CT, Da-Costa AC, Tavares CR (2009) Characterization of solids originating from the Fenton's process. J Hazard Mater 163(2-3): 12461253.

38. Huang CP, Dong C, Tang Z (1993) Advanced chemical oxidation: its present role and potential future in hazardous waste treatment. Waste Mgmt 13(5-7): 361-377.

39. Pouran SR, Abdul Aziz AR, Daud W (2014) Review on the main advances in photo-Fenton oxidation system for recalcitrant wastewaters. J Ind Eng Chem 21: 53-69.

40. Punzi M, Mattiasson B, Jonstrup M (2012) Treatment of synthetic textile wastewater by homogeneous and heterogeneous photo-Fenton oxidation. J Photochem Photobiol A: Chem 248: 30-35.

41. Méndez-Arriaga F, Esplugas S, Giménez J (2010) Degradation of the emerging contaminant ibuprofen in water by photo-Fenton. Water Res 44(2): 589-595.

42. Gonzalez-Olmos R., Martin MJ, Georgi A, Kopinke FD, Oller I, et al (2012) Fe-zeolites as heterogeneous catalysts for solar Fenton-like reactions at neutral pH. Appl Catal B: Environ 125: 51-58.
43. Casbeer E, Sharma VK, Li XZ (2012) Synthesis and photocatalytic activity of ferrites under visible light: A review Sep Purif Technol 87: $1-14$.

44. Garrido-Ramirez EG, Theng BK, Mora ML (2010) Clays and oxide minerals as catalysts and nanocatalysts in Fenton-like reactions - A review. Appl Clay Sci 47(3-4): 182-192.

45. Herney-Ramirez J, Vicente MA, Madeira LM (2010) Heterogeneous photo-Fenton oxidation with pillared clay-based catalysts for wastewater treatment: A review. Appl Catal B: Environ 98(1-2): 10-26

46. Soon AN, Hameed BH (2011) Heterogeneous catalytic treatment of synthetic dyes in aqueous media using Fenton and photo-assisted Fenton process. Desalination 269(1-3): 1-16.

47. Navalon S, Alvaro M, Garcia H (2010) Heterogeneous Fenton catalysts based on clays, silicas and zeolites. Appl Catal B: Environ 99(1-2): 1-26.

48. Yoon J, Cho S, Cho Y, Kim S (1998) The characteristics of coagulation of Fenton reaction in the removal of landfill leachate organics. Wat Sci Technol 38(2): 209-214.

49. Wei TY, Wang YY, Wan CC (1990) Photocatalytic oxidation of phenol in the presence of hydrogen peroxide and titanium dioxide powders. J Photochem Photobiol A: Chem 55(1): 115-126.

50. Lipczynska-Kochany A (1991) Novel method for a photocatalytic degradation of 4-nitrophenol in homogeneous aqueous solution. Environ Technol 12: 87-92.

51. Ruppert G, Bauer R (1993) Mineralization of cyclic organic water contaminants by the photo-Fenton reaction: influence of structure and substituents. Chemosphere 27(8): 1339-1347.

52. Daneshvar N, Behnajady MA, Khayyat AM, Mohammadi MS, Dorraji $\mathrm{S}$ (2008) $\mathrm{UV} / \mathrm{H}_{2} \mathrm{O}_{2}$ treatment of Rhodamine $\mathrm{B}$ in aqueous solution: Influence of operational parameters and kinetic modeling. Desalination 230(1): 16-26.

53. Ayodele OB, Lim JK, Hameed BH (2012) Degradation of phenol in photo-Fenton process by phosphoric acid modified kaolin supported ferric-oxalate catalyst: Optimization and kinetic modeling. Chem Eng J 197: 181-192.

54. Katsumata H, Kaneco S, Suzuki T, Ohta K, Yobiko Y (2005) Degradation of linuron in aqueous solution by the photo-Fenton reaction. Chem Eng J 108(3): 269-276.

55. Rivas FJ, Beltrán FJ, Frades J, Buxeda P (2001) Oxidation of p-hydroxybenzoic acid by Fenton's reagent. Water Res 35(2): 387-396.

56. Eisenhauer HR (1964) Oxidation of phenolic wastes. J Water Pollut Control Fed 36(9): 1116-1128.

57. Ma YS, Huang ST, Lin JG (2000) Degradation of 4-nitro phenol using the Fenton process. Water Sci Technol 42(3-4): 155-160.

58. Babuponnusami A, Muthukumar K (2011) Degradation of phenol in aqueous solution by Fenton, sono-Fenton, Sono-photo-Fenton methods. Clean-Soil Air Water 39(2): 142-147.

59. Parsons S (2004) Advanced Oxidation Processes for Water and Wastewater Treatment. IWA Publishing, London, UK.

60. Szpyrkowicz L, Juzzolino C, Kaul SN (2001) A Comparative study on oxidation of disperse dye by electrochemical process, ozone, hypochlorite and Fenton reagent. Water Res 35(9): 2129-2136.

61. Kim SM, Vogelpohl A (1998) Degradation of organic pollutants by the photo-Fenton process. Chem Eng Technol 21(2): 187-191.

62. Gaberell M, Chin YP, Hug SJ, Sulzberger B (2003) Role of dissolved organic matter composition on the photoreduction of $\mathrm{Cr}$ (VI) to $\mathrm{Cr}$ (III) in the presence of iron. Environ Sci Technol 37(19): 4403-4409.

63. Shemer H, Kunukcu YK, Linden KG (2006) Degradation of the 
pharmaceutical metronidazole via UV, Fenton and photo-Fenton processes. Chemosphere 63(2): 269-276.

64. Nitoi I, Oncescu T, Oancea P (2013) Mechanism and kinetic study for the degradation of lindane by photo-Fenton process. J Ind Eng Chem 19(1): 305-309.

65. Tamimi M, Qourzal S, Barka N, Assabbane A, Ait-Ichou Y (2008) Methomyl degradation in aqueous solutions by Fenton's reagent and the photo-Fenton system. Sep Purif Techno 61(1): 103-108.

66. Kavitha V, Palanivelu K (2005) Destruction of cresols by Fenton oxidation process. Water Res 39(13): 3062-3072.

67. Xu XR, Li XY, Li XZ, Li HB (2009) Degradation of melatonin by UV, UV/ $\mathrm{H}_{2} \mathrm{O}_{2}, \mathrm{Fe}^{2+} / \mathrm{H}_{2} \mathrm{O}_{2}$ and $\mathrm{UV} / \mathrm{Fe}^{2+} / \mathrm{H}_{2} \mathrm{O}_{2}$ processes. Sep Purif Technol 68(2): 261-266.

68. Kwon BG, Lee DS, Kang N, Yoon J (1999) Characteristics of p-chlorophenol oxidation by Fentons reagent. Water Res 33(9): 21102118.

69. Benitez FJ, Acero JL, Real FJ, Rubio FJ, Leal A.I (2001) The role of hydroxyl radicals for the decomposition of p-hydroxy phenylacetic acid in aqueous solutions. Water Res 35(5): 1338-1343.

70. Pignatello JJ (1992) Dark and photoassisted $\mathrm{Fe}^{3+}$-catalyzed degradation of chlorophenoxy herbicides by hydrogen peroxide. Environ Sci Technol 26(5): 944-951.

71. Lin SH, Lo CC (1997) Fenton process for treatment of desizing wastewater. Water Res 31(8): 2050-2056.

72. Lin SH, Lin CM, Leu HG (1999) Operating characteristics and kinetics studies of surfactant wastewater treatment by Fenton oxidation. Water Res 33(7): 1735-1741.

73. Kang YW, Hwang KY (2000) Effects of reaction conditions on the oxidation efficiency in the Fenton process. Water Res 34(10): 27862790 .

74. Ito K, Jian W, Nishijima W, Baes AU, Shoto E, et al. (1998) Comparison of ozonation and AOPs combined with biodegradation for removal of THM precursors in treated sewage effluents. Water Sci Technol 38(7): 179-186.

75. Monteagudo JM, Durán A, Aguirre M, San Martín I (2011) Optimization of the mineralization of a mixture of phenolic pollutants under a ferrioxalate-induced solar photo-Fenton process. J Hazard Mater 185(1): 131-139.

76. Primo 0, Rivero MJ, Ortiz I (2008) Photo-Fenton process as an efficient alternative to the treatment of landfill leachates. J Hazard Mater 153(12): 834-842.

77. González O, Sans C, Esplugas S (2007) Sulfamethoxazole abatement by photo-Fenton: toxicity, inhibition and biodegradability assessment of intermediates. J Hazard Mater 146(3): 459-464.

78. Yip AC, Lam FL, Hu X (2005) Chemical-vapor-deposited Copper on Acid-activated Bentonite Clay as an Applicable Heterogeneous Catalyst for the photo-Fenton-like Oxidation of Textile Organic Pollutants. Ind Eng Chem Res 44(21): 7983-7990.

79. Muthukumari B, Selvam K, Muthuvel I, Swaminathan M (2009) Photoassisted hetero-Fenton mineralisation of azo dyes by $\mathrm{Fe}(\mathrm{II})-\mathrm{Al}_{2} \mathrm{O}_{3}$ catalyst. Chem Eng J 153(1-3): 9-15.

80. Kamal MA, Klein P (2010) Estimation of BTEX in groundwater by using gas chromatography-mass spectrometry. Saudi J Biol Sci 17: 205-208.

81. Nesheiwat FK, Swanson AG (2000) Clean contaminated sites using Fenton's reagent. Chem Eng Prog 96(4): 61-66.

82. Zapata A, Oller I, Rizzo L, Hilgert S, Maldonado MI, et al. (2010) Evaluation of operating parameters involved in solar photo-Fenton treatment of wastewater: Interdependence of initial pollutant concentration, temperature and iron concentration. Appl Catal B: Environ 97(1-2): 292-298.

83. Ravina M, Campanella L, Kiwi J (2002) Accelerated mineralization of the drug Diclofenac via Fenton reactions in a concentric photo-reactor. Water Res 36(14): 3553-3560.

84. Ortega-Lie bana MC, Sanchez-Lopez E, Hidalgo-Carrillo J, Marinas A, Marinas JM, et al. (2012) A comparative study of photocatalytic degradation of 3-chloropyridine under UV and solar light by homogeneous (photo-Fenton) and heterogeneous $\left(\mathrm{TiO}_{2}\right)$ photocatalysis. Appl Catal B: Environ 127: 316-322.

85. Klamerth N, Rizzo L, Malato S, Maldonado MI, Aguera A, et al. (2010) Degradation of fifteen emerging contaminants at [mu]g L-1 initial concentrations by mild solar photo-Fenton in MWTP effluents. Water Res 44: 545-554.

86. Sirtori C, Zapata A, Gernjak W, Malato S, Lopez A, et al. (2011) Solar photo-Fenton degradation of nalidixic acid in waters and wastewaters of different composition. Analytical assessment by LC-TOF-MS. Water Res 45(4): 1736-1744.

87. Luna AJ, Chiavone-Filho O, Machulek A Jr, de Moraes JE, Nascimento CA (2012) Photo-Fenton oxidation of phenol and organochlorides (2, 4-DCP and 2, 4-D) in aqueous alkaline medium with high chloride concentration. J Environ Manage 111: 10-17.

88. De Laat J, Le TG (2006) Effects of chloride ions on the iron (III)catalyzed decomposition of hydrogen peroxide and on the efficiency of the Fenton-like oxidation process. Appl Catal B: Environ 66(1-2): 137-146.

89. Devi LG, Raju KS, Kumar SG, Rajashekhar KE (2011) Photo-degradation of di azo dye Bismarck Brown by advanced photo-Fenton process: Influence of inorganic anions and evaluation of recycling efficiency of iron powder. J Taiwan Inst Chem Eng 42(2): 341-349.

90. Mico MM, Bacardit J, Malfeito J, Sans C (2013) Enhancement of pesticide photo-Fenton oxidation at high salinities. Appl Catal B: Environ 132133: $162-169$.

91. Xue X, Hanna K, Despas C, Wu F, Deng N (2009) Effect of chelating agent on the oxidation rate of PCP in the magnetite $/ \mathrm{H}_{2} \mathrm{O}_{2}$ system at neutral pH. J Mol Catal A: Chem 311(1-2): 29-35.

92. Huang W, Brigante M, Wu F, Hanna K, Mailhot G (2012) Development of a new homogenous photo-Fenton process using Fe(III)-EDDS complexes. J Photochem Photobiol A: Chem 239: 17-23.

93. An J, Zhu L, Zhang Y, Tang H (2013) Efficient visible light photo-Fentonlike degradation of organic pollutants using in situ surface-modified $\mathrm{BiFeO}_{3}$ as a catalyst. J Environ Sci (China) 25(6): 1213-1225.

94. Klamerth N, Malato S, Aguera A, Fernandez-Alba A (2013) PhotoFenton and modified photo-Fenton at neutral $\mathrm{pH}$ for the treatment of emerging contaminants in wastewater treatment plant effluents: a comparison. Water Res 47(2): 833-840.

95. Duesterberg CK, Cooper WJ, Waite TD (2005) Fenton-mediated oxidation in the presence and absence of oxygen. Environ Sci Technol 39(13): 5052-5058.

96. Mulazzani QG, D’Angelantonio M, Venturi M, Hoffman MZ, Rodgers MA (1986) Interaction of formate and oxalate ions with radiationgenerated radicals in aqueous solution. Methylviologen as a mechanistic probe. J Phys Chem 90(21): 5347-5352.

97. Ruppert G, Bauer R, Heisler G (1993) The photo-Fenton reaction - an effective photochemical wastewater treatment process. J Photochem Photobiol A-Chem 73(1): 75-78.

98. Sun Y, Pignatello JJ (1993) Photochemical reactions involved in the total mineralization of 2,4-D by $\mathrm{Fe}^{3+} / \mathrm{H}_{2} \mathrm{O}_{2} / \mathrm{UV}$. Environ Sci Technol 27(2): 304-310. 
99. Gogate PR, Pandit AB (2004) A review of imperative technologies for wastewater treatment II: hybrid methods. Adv Environ Res 8(3-4): 553-597.

100. Faust BC, Hoigne J (1990) Photolysis of Fe(III)-hydroxy complexes as sources of $\mathrm{OH}$ radicals in clouds, fog and rain. Atmos Environ 24(1): 79-89.

101. Bauer R, Fallmann H (1997) The photo-Fenton oxidation - a cheap and efficient wastewater treatment method. Res Chem Intermed 23(4): 341-354.

102. Zepp RG, Faust BC, Hoigne J (1992) Hydroxyl radical formation in aqueous reactions ( $\mathrm{pH} 3-8)$ of iron(II) with hydrogen peroxide: the photo-Fenton reaction. Environ Sci Technol 26(2): 313-319.

103. McGinnis BD, Adams VD, Middlebrooks EJ (2000) Degradation of ethylene glycol in photo Fenton systems. Water Res 34(8): 23462354 .

104. Amat AM, Arques A, Miranda MA, Segui S (2004) Photo-Fenton reaction for the abatement of commercial surfactants in a solar pilot plant. Sol Energy 77(5): 559-566.

105. Wu C, Liu X, Wej D, Fan J, Wang L (2001) Photosonochemical degradation of phenol in water. Water Res 35(16): 3927-3933.

106. Pradhan AA, Gogate PR (2010) Degradation of p-nitrophenol using acoustic cavitation and Fenton chemistry. J Hazard Mater 173(1-3) 517-522.

107. Ting WP, Lu MC, Huang YH (2008) The reactor design and comparison of Fenton, electro-Fenton and photoelectron-Fenton processes for mineralization of benzene sulfonic acid (BSA). J Hazard Mater 156(13): 421-427.

108. Mendez Arriaga F, Torres-Palma RA, Petrier C, Esplugas S, Gimenez $J$, et al. (2009) Mineralization enhancement of a recalcitrant pharmaceutical pollutant in water by advanced oxidation hybrid processes. Water Res 43(16): 3984-3991.

109. Joseph JM, Destaillats H, Hung HM, Hoffmann MR (2000) The sonochemical degradation of azobenzene and related azo dyes: rate enhancements via Fenton's reactions. J Phys Chem A 104(2): 301307.

110. Minero C, Lucchiari M, Vione D, Maurino V (2005) Fe(III)-enhanced sonochemical degradation of methylene blue in aqueous solution. Environ Sci Technol 39(22): 8936-8942.

111. Adewuyi YG (2005) Sonochemistry in environmental remediation 1. Combinative and hybrid sonophotochemical oxidation processes for the treatment of pollutants in water. Environ Sci Technol 39(10): 3409-3420.

112. Li H, Lei H, Yu Q, Li Z, Feng X, et al. (2010) Effect of low frequency ultrasonic irradiation on the sonoelectro-Fenton degradation of cationic red X-GRL. Chem Eng J 160(2): 417-422.

113. Boye B, Dieng MM, Brillas E (2002) Degradation of herbicide 4-chlorophenoxyacetic acid by advanced electrochemical oxidation methods. Environ Sci Technol 36(13): 3030-3035.

114. Babuponnusami A, Muthukumar K (2012) Advanced oxidation of phenol: a comparison between Fenton, electro-Fenton, sono-electroFenton and photo-electro-Fenton processes. Chem Eng J 183: 1-9.

115. Brillas E, Banos MA, Garrido JA (2003) Mineralization of herbicide 3,6-dichloro-2- methoxybenzoic acid in aqueous medium by anodic oxidation, electro-Fenton and photoelectro-Fenton", Electrochim Acta 48(12): 1697-1705.

116. Boye B, Dieng MM, Brillas E (2003) Anodic oxidation, electro-Fenton and photoelectro-Fenton treatments of 2,4,5-trichlorophenoxyacetic acid. J Electroanal Chem 557: 135-146.
117. Brillas E, Boye B, Dieng MM (2003) General, UV-assisted cathodic Fenton treatments for the mineralization of herbicide MCPA. J Electrochem Soc 150(11): 583- 589.

118. Irmak S, Yavuz HI, Erbatur O (2006) Degradation of 4-chloro2-methylphenol in aqueous solution by electro-Fenton and photoelectro-Fenton processes. Appl Catal B Environ 63(3-4): 243248.

119. Flox C, Ammar S, Arias C, Brillas E, Vargas-Zavala, et al. (2006) Electro- Fenton and photoelectro-Fenton degradation of indigo carmine in acidic aqueous medium. Appl Catal B Environ 67(1-2): 93-104.

120. Flox C, Garrido JA, Rodriguez RM, Cabot PL, Centellas F, et al. (2007) Mineralization of herbicide mecoprop by photoelectro-Fenton with UVA and solar light. Catal Today 129(1-2): 29-36.

121. Prato-Garcia D, Buitron G (2012) Evaluation of three reagent dosing strategies in a photo-Fenton process for the decolorization of azo dye mixtures. J Hazard Mater 217-218: 293-300.

122. Tokumura M, Morito R, Kawase Y (2013) Photo-Fenton process for simultaneous colored wastewater treatment and electricity and hydrogen production. Chem Eng J 221: 81-89.

123. Garcia-Montano J, Perez-Estrada L, Oller I, Maldonado MI, Torrades F, et al. (2008) Pilot plant scale reactive dyes degradation by solar photo-Fenton and biological processes. J Photochem Photobiol A Chem 195(2-3): 205-214.

124. Hernandez Rodriguez MJ, Fernandez-Rodriguez C, Dona-Rodriguez JM, Gonzalez-Diaz OM, Zerbani D, et al. (2014) Treatment of effluents from wool dyeing process by photo-Fenton at solar pilot plant. J Environ Chem Eng 2(1): 163-171.

125. Modenes AN, Espinoza-Quinones FR, Manenti DR, Borba FH, Palacio SM, et al. (2012) Performance evaluation of a photo-Fenton process applied to pollutant removal from textile effluents in a batch system. J Environ Manage 104: 1-8.

126. Torrades F, Garcia Montano J (2014) Using central composite experimental design to optimize the degradation of real dye wastewater by Fenton and photo-Fenton reactions. Dyes \& Pigments 100: 184-189.

127. Blanco J, Torrades F, Moron M, Brouta Agnesa M, Garcia Montano J (2014) Photo-Fenton and sequencing batch reactor coupled to photoFenton processes for textile wastewater reclamation: Feasibility of reuse in dyeing processes. Chem Eng J 240: 469-475.

128. Ioannou LA, Fatta Kassinos D (2013) Solar photo-Fenton oxidation against the bioresistant fractions of winery wastewater. J Environ Chem Eng 1(4): 703-712.

129. Fernandes L, Lucas MS, Maldonado MI, Oller I, Sampaio A (2014) Treatment of pulp mill wastewater by Cryptococcus podzolicus and solar photo-Fenton: a case study. Chem Eng J 245: 158-165.

130. De Torres Socias E, Fernandez-Calderero I, Oller I, Trinidad-Lozano MJ, Yuste FJ, et al. (2013) Cork boiling wastewater treatment at pilot plant scale: Comparison of solar photo-Fenton and ozone $\left(\mathrm{O}_{3}, \mathrm{O}_{3} /\right.$ $\mathrm{H}_{2} \mathrm{O}_{2}$ ). Chem Eng J 234: 232-239.

131. Vilar VJP, Moreira FC, Ferreira ACC, Sousa MA, Goncalves C, et al. (2012) Biodegradability enhancement of a pesticide-containing bio-treated wastewater using a solar photo-Fenton treatment step followed by a biological oxidation process. Water Res 46(15): 45994613.

132. Sirtori C, Zapata A, Oller I, Gernjak W, Aguera A, et al. (2009) Decontamination industrial pharmaceutical wastewater by combining solar photo-Fenton and biological treatment. Water Res 43(3): 661-668.

133. De Oliveira IS, Viana L, Verona C, Fallavena VLV, Nunes Azevedo CM 
et al. (2007) Alkydic resin wastewaters treatment by Fenton and photo-Fenton processes. J Hazard Mater 146(3): 564-568.

134. Zheng H, Pan Y, Xiang X (2007) Oxidation of acidic dye Eosin Y by the solar photo-Fenton processes. J Hazard Mater 141(3): 457-464.

135. Walter MV, Vennes JW (1985) Occurrence of multiple-antibioticresistant enteric bacteria in domestic sewage and oxidation lagoons. Appl Environ Microbiol 50(4): 930-933.

136. Laville N, AitAissa S, Gomez E, Casellas C, Porcher JM (2004) Effects of human pharmaceuticals on cytotoxicity, EROD activity and ROS production in fish hepatocytes. Toxicology 196(1-2): 41-55.

137. Alaton I, Dogruel S, Baykal E, Gerone G (2004) Combined chemical and biological oxidation of penicillin formulation effluent. J Environ Manage 73(2): 155-163.

138. Bredhult C, Backlin B, Olovsson M (2007) Effects of some endocrine disruptors on the proliferation and viability of human endometrial endothelial cells in vitro. Reprod Toxicol 23(4): 550-559.

139. Chatzitakis A, Berberidou C, Paspaltsis I, Kyriakou G, Sklaviadis T (2008) Photocatalytic degradation and drug activity reduction of Chloramphenicol. Water Res(1-2): 386-394.

140. Nakada N, Shinohara H, Murata A, Kiri K, Managaki S, et al. (2007) Removal of selected pharmaceuticals and personal care products (PPCPs) and endocrine-disrupting chemicals (EDCs) during sand filtration and ozonation at a municipal sewage treatment plant. Water Res 41(1-2): 4373-4382.

141. Gogate PR, Pandit AB (2004) A review of imperative technologies for wastewater treatment I: oxidation technologies at ambient conditions. Adv Environ Res 8(3-4): 501-551.

142. Pereira V, Linden K, Weinberg H (2007) Evaluation of UV irradiation for photolytic and oxidative degradation of pharmaceutical compounds in water. Water Res 41: 4413-4423.

143. Gotvajn AZ, Zagorc-Koncan J, Tisler TP (2007) "Pretreatment of Highly Polluted Pharmaceutical Waste Broth by Wet Air Oxidation. J Environ Eng ASCE 133(1): 89-94.

144. Xing MY, Deng C, Godefroid B, Jian Y (2006) Treatment of pharmaceutical wastewater containing recalcitrant compounds in a Fenton coagulation process. J Environ Sci 18(3): 459-463.

145. Trovo AG, Pupo Nogueira RF, Aguera A, Fernandez-Alba AR, Malato S (2012) Paracetamol degradation intermediates and toxicity during photo-Fenton treatment using different iron species. Water Res 46(16): 5374-5380.

146. De Lima Perini JA, Perez-Moya M, Nogueira RFP (2013) PhotoFenton degradation kinetics of low ciprofloxacin concentration using different iron sources and pH. J Photoch Photobio A 259: 53-58.

147. Trovo AG, Pupo Nogueira RF, Aguera A, Fernandez-Alba AR, Malato S (2011) Degradation of the antibiotic amoxicillin by photo-Fenton process - Chemical and toxicological assessment. Water Res 45(3): 1394-1402.

148. Kajitvichyanukul P, Suntronvipart N (2006) Evaluation of biodegradability and oxidation degree of hospital wastewater using photo-Fenton process as the pretreatment method. J Hazard Mater 138(2): 384-391.

149. Miralles Cuevas S, Oller I, Ruiz Aguirre A, Sanchez Perez JA, Malato Rodriguez S (2014) Removal of pharmaceuticals at microg L-1 by combined nanofiltration and mild solar photo-Fenton. Chem Eng J 239: 68-74.

150. Hajslova J, Moffat CF, Whittle KJ (1999) Pesticides: Environmental Contaminants in Food. Sheffield Academic Press, USA, pp. 215-272.

151. Carvalho FP (2006) Agriculture, pesticides, food security and food safety. Environ Sci Policy 9(7-8): 685-692.
152. International Agency for Research on Cancer (1987) IARC Monographs on the Evaluation of Carcinogenic Risks to Humans. IARC, 1212 Lyon, France, p. 40-51.

153. Zhang Y and Pagilla K (2010) Treatment of malathion pesticide wastewater with nanofiltration and photo-Fenton oxidation. Desalination 263(1-3): 36-44.

154. Teixeira ACSC, Mendes L, Stollar G, Guardani D RCAO, Nascimento D (2005) Photo-Fenton remediation of wastewaters containing agrochemicals. Braz Arch Biol Techn 48: 207-218.

155. Strathmann TJ, Stone AT (2001) Reduction of the carbamate pesticides oxamyl and methomyl by dissolved $\mathrm{Fe}(\mathrm{II})$ and $\mathrm{Cu}(\mathrm{I})$. Environ Sci Technol 35(12): 2461-2469.

156. Maldonado MI, Passarinho PC, Oller I, Gernjak W, Fernandez P, et al. (2007) Photocatalytic degradation of EU priority substances: A comparison between $\mathrm{TiO}_{2}$ and Fenton plus photo-Fenton in a solar pilot plant. J Photoch Photobio A 185(2-3): 354-363.

157. Beychok MR (1967) Aqueous Wastes from Petroleum and Petrochemical Plants. ( $1^{\text {st }}$ edn), John Wiley \& Sons, New York, USA.

158. Coelho A, Castro AV, Dezotti M, Sant Anna Jr GL (2006) Treatment of petroleum refinery sourwater by advanced oxidation processes. J Hazard Mater 137(1): 178-184.

159. Santos MRG, Goulart MOF, Tonholo J, Zanta CLPS (2006) The application of electrochemical technology to the remediation of oily wastewater. Chemosphere 64(3): 393-399.

160. Stepnowski P, Siedlecka EM, Behrend P, Jastorff B (2002) Enhanced photo-degradation of contaminants in petroleum refinery wastewater. Water Res 36(9): 2167-2172.

161. Wake H (2005) Oil refineries: a review of their ecological impacts on the aquatic environment. Est Coast Shelf Sci 62(1-2): 131-140.

162. Reddy C, Quinn J (1999) GC-MS analysis of total petroleum hydrocarbons and polycyclic aromatic hydrocarbons in seawater samples after the North Cape oil spill. Marine Poll Bull 38(2): 126135.

163. IPIECA (2010) Petroleum Refining Water/Wastewater Use and Management, Operations Best Practice, London, UK.

164. Hasan DUB, Abdul Aziz AR, Daud WMAW (2012) Oxidative mineralisation of petroleum refinery effluent using Fenton-like process. Chem Eng Res Des 90(2): 298-307.

165. El-Naas MH, Al-Zuhair S, Abu Alhaija M (2010) Reduction of COD in refinery wastewater through adsorption on date-pit activated carbon. J Hazard Mater 173(1-3): 750-757.

166. Verma S, Prasad B, Mani Mishra I (2010) Pretreatment of petrochemical wastewater by coagulation and flocculation and the sludge characteristics. J Hazard Mater 178(1-3): 1055-1064.

167. Chan H (2011) Biodegradation of petroleum oil achieved by bacteria and nematodes in contaminated water. Sep Purif Technol 80(3): 459466.

168. Yan L, Ma H, Wang B, Wang Y, Chen Y (2011) Electrochemical treatment of petroleum refinery wastewater with three-dimensional multi-phase electrode. Desalination 276(1-3): 397-402.

169. Bernardo P, Drioli E (2010) Membrane Technology. Elsevier, Netherlands, pp. 211-239

170. Sun Y, Zhang Y, Quan X (2008) Treatment of petroleum refinery wastewater by microwave-assisted catalytic wet air oxidation under low temperature and low pressure. Sep Purif Technol 62(3): 565570 .

171. Galvao SAO, Mota ALN, Silva DN, Moraes JEF, Nascimento CAO (2006) Application of the photo-Fenton process to the treatment of 
wastewaters contaminated with diesel. Sci Tot Environ 367(1): 4249.

172. Diya'uddeen BH, Daud WMAW, Abdul Aziz AR (2011) Treatment technologies for petroleum refinery effluents: A review. Process Saf Environ 89(2): 95-105.

173. Da Silva SS, Chiavone-Filho O, de Barros Neto EL, Nascimento CAO (2012) Integration of processes induced air flotation and photoFenton for treatment of residual waters contaminated with xylene. J Hazard Mater 199-200: 151-157.

174. Murphy AP (1991) Chemical removal of nitrate from water. Nature 350: 223-225

175. Lien HL, Wilkin R (2002) Reductive activation of dioxygen for degradation of methyl tert-butyl ether by bifunctional aluminum. Environ Sci Technol 36(20): 4436-4440.

176. Lien HL, Zhang W (2002) Novel bifunctional aluminum for oxidation of MTBE and TAME. J Environ Eng 128(9): 791-798.

177. Bokare AD, Choi W (2009) Zero-valent aluminum for oxidative transformation of aqueous organic pollutants. Environ Sci Technol 43(18): 7130-7135.

178. Mamontov E, Egami T, Brezny R, Koranne M, Tyagi S (2000) Lattice defects and oxygen storage capacity of nanocrystalline ceria and ceria-zirconia. J Phys Chem B 104: 11110-11116.

179. Campbell CT, Peden CH (2005) Chemistry. Oxygen vacancies and catalysis on ceria surfaces. Science 309(5735): 713-714.

180. Trovarelli A, de Leitenburg C, Boaro M, Dolcetti G (1999) The utilization of ceria in industrial catalysis. Catal Today 50(2): 353-367.

181. Cai W, Chen F, Shen X, Chen L, Zhang J (2010) Enhanced catalytic degradation of $\mathrm{AO}_{7}$ in the $\mathrm{CeO}_{2}-\mathrm{H}_{2} \mathrm{O}_{2}$ system with $\mathrm{Fe}^{3+}$ doping. Appl Catal B Environ 101(1-2): 160-168.

182. Ji P, Wang L, Chen F, Zhang J (2010) $\mathrm{Ce}^{3+}$-centric organic pollutant elimination by $\mathrm{CeO}_{2}$ in the presence of $\mathrm{H}_{2} \mathrm{O}_{2}$ Chem Cat Chem 2(12): 1552-1554.

183. Chen F, Shen X, Wang Y, Zhang J (2012) $\mathrm{CeO}_{2} / \mathrm{H}_{2} \mathrm{O}_{2}$ system catalytic oxidation mechanism study via a kinetics investigation to the degradation of acid orange 7. Appl Catal B Environ 121-122: 223229.

184. Wang Y, Shen X, Chen F (2014) Improving the catalytic activity of $\mathrm{CeO}_{2} / \mathrm{H}_{2} \mathrm{O}_{2}$ system by sulfation pretreatment of $\mathrm{CeO}_{2}$. J Mol Catal A Chem 381: 38-45.

185. Asati A, Santra S, Kaittanis C, Perez JM (2010) Surface-chargedependent cell localization and cytotoxicity of cerium oxide nanoparticles. ACS Nano 4(9): 5321-5331.

186. Levina A, Lay PA (2005) Mechanistic studies of relevance to the biological activities of chromium. Coord Chem Rev 249(3-4): 281298.

187. Codd R, Dillon CT, Levina A, Lay PA (2001) Studies on the genotoxicity of chromium: from the test tube to the cell. Coord Chem Rev 216-217: 537-582.

188. Bokare AD, Choi W (2010) Chromate-induced activation of hydrogen peroxide for oxidative degradation of aqueous organic pollutants. Environ Sci Technol 44(19): 7232-7237.

189. Vander Griend DA, Golden JS, ArringtonJr CA (2002) Kinetics and mechanism of chromate reduction with hydrogen peroxide in base. Inorg Chem 41(26): 7042-7048.

190. Anipsitakis GP, Dionysiou DD (2003) Degradation of organic contaminants in water with sulfate radicals generated by the conjunction of peroxymonosulfate with cobalt. Environ Sci Technol 37(20): 4790-4797.
191. Anipsitakis GP, Dionysiou DD (2004) Radical generation by the interaction of transition metals with common oxidants. Environ Sci Technol 38(13): 3705-3712.

192. Ling SK, Wang S, Peng Y (2010) Oxidative degradation of dyes in water using $\mathrm{Co}^{2+} / \mathrm{H}_{2} \mathrm{O}_{2}$ and $\mathrm{Co}^{2+} /$ peroxymonosulfate. J Hazard Mater 178(1-3): 385-359.

193. Kuo CY, Pai CY, Wu CH, Jian MY (2012) Effects of oxidant concentration and temperature on decolorization of azo dye: comparisons of UV/ Fenton and UV-Fentonlike systems. Water Sci Technol 65(11): 19701974.

194. Pimentel M, Oturan N, Dezotti M, Oturan MA (2008) Phenol degradation by advanced electrochemical oxidation process electroFenton using a carbon felt cathode. Appl Catal B Environ 83(1-2): 140-149.

195. Salem IA, El-Maazawi MS (2000) Kinetics and mechanism of color removal of methylene blue with hydrogen peroxide catalyzed by some supported alumina surfaces. Chemosphere 41(8): 1173-1180.

196. Chaliha S, Bhattacharyya KG (2008) Wet oxidative method for removal of 2,4,6- trichlorophenol in water using Fe(III), Co(II), Ni(II) supported MCM41 catalysts. J Hazard Mater 150(3): 728-736.

197. Duarte F, Maldonado-Hodar FJ, Perez-Cadenas AF, Madeira LM (2009) Fentonlike degradation of azo-dye Orange II catalyzed by transition metals on carbon aerogels. Appl Catal B Environ 85(3-4): 139-147.

198. Millero FJ, Johnson RL, Vega CA, Sharma VK, Sotolongo S (1992) Effect of ionic interactions on the rates of reduction of $\mathrm{Cu}(\mathrm{II})$ with $\mathrm{H}_{2} \mathrm{O}_{2}$ in aqueous solutions. J Solution Chem 21: 1271-1287.

199. Nieto Juarez JI, Pierzchla K, Sienkiewicz A, Kohn T (2010) Inactivation of MS2 coliphage in Fenton and Fenton-like systems: role of transition metals, hydrogen peroxide and sunlight. Environ Sci Technol 44(9): 3351-3356.

200. Sires I, Garrido JA, Rodriguez RM, Cabot PLL, Centellas F, et al. (2006) Electrochemical degradation of paracetamol from water by catalytic action of $\mathrm{Fe}^{2+}, \mathrm{Cu}^{2+}$ and UVA light on electro generated hydrogen peroxide. J Electrochem Soc 153(1): D1-D9.

201. Salazar R, Brillas E, Sires I (2012) Finding the best $\mathrm{Fe}^{2+} / \mathrm{Cu}^{2+}$ combination for the solar photoelectron-Fenton treatment of simulated wastewater containing the industrial textile dye Disperse Blue 3. Appl Catal B Environ 115-116: 107-116.

202. Morgan JJ (2000) Manganese in natural waters and earth's crust: its availability to organisms, in: A Sigel, H Sigel (eds), Metal Ions in Biological Systems Volume 37: Manganese and its Role in Biological Processes. Marcell Dekker Inc, New York, USA, p. 1-34.

203. Driehaus W, Seith R, Jekel M (1995) Oxidation of arsenate (III) with manganese oxides in water treatment. Water Res 29(1): 297-305.

204. Han YF, Chen F, Zhong Z, Ramesh K, Chen L, et al. (2007) Complete oxidation of low concentration ethanol in aqueous solution with $\mathrm{H}_{2} \mathrm{O}_{2}$ on nanosized $\mathrm{Mn}_{3} \mathrm{O}_{4} / \mathrm{SBA}-15$ catalyst. Chem Eng J 134(1-3): 276-281.

205. Pagliaro M, Campestrini S, Ciriminna R (2005) Ru-based oxidation catalysis. Chem Soc Rev 34(10): 837-845.

206. Hu Z, Leung CF, Tsang YK, Du H, Liang H, et al. (2011) A recyclable polymer-supported ruthenium catalyst for the oxidative degradation of bisphenol A in water using hydrogen peroxide. New J Chem 35(1): 149-155.

207. Rokhina EV, Lahtinen M, Nolte MCM, Virkutyte J (2009) The influence of ultrasound on the $\mathrm{RuI}_{3}$-catalyzed oxidation of phenol: catalyst study and experimental design. Appl Catal B Environ 87(3-4): 162170 . 
This work is licensed under Creative Commons Attribution 4.0 Licens

DOI: 10.19080/IJESNR.2017.02.555594
Your next submission with Juniper Publishers will reach you the below assets

- Quality Editorial service

- Swift Peer Review

- Reprints availability

- E-prints Service

- Manuscript Podcast for convenient understanding

- Global attainment for your research

- Manuscript accessibility in different formats ( Pdf, E-pub, Full Text, Audio)

- Unceasing customer service

Track the below URL for one-step submission https://juniperpublishers.com/online-submission.php 